\title{
De doorstroom van het initieel naar het niet-initieel onderwijs
}

Citation for published version (APA):

de Grip, A., \& Jacobs, A. (1999). De doorstroom van het initieel naar het niet-initieel onderwijs.

Researchcentrum voor Onderwijs en Arbeidsmarkt, Faculteit der Economische Wetenschappen. ROA Working Papers No. 3 https://doi.org/10.26481/umarow.1999003

Document status and date:

Published: 01/01/1999

DOI:

10.26481/umarow.1999003

Document Version:

Publisher's PDF, also known as Version of record

\section{Please check the document version of this publication:}

- A submitted manuscript is the version of the article upon submission and before peer-review. There can be important differences between the submitted version and the official published version of record.

People interested in the research are advised to contact the author for the final version of the publication, or visit the DOI to the publisher's website.

- The final author version and the galley proof are versions of the publication after peer review.

- The final published version features the final layout of the paper including the volume, issue and page numbers.

Link to publication

\footnotetext{
General rights rights.

- You may freely distribute the URL identifying the publication in the public portal. please follow below link for the End User Agreement:

www.umlib.nl/taverne-license

Take down policy

If you believe that this document breaches copyright please contact us at:

repository@maastrichtuniversity.nl

providing details and we will investigate your claim.
}

Copyright and moral rights for the publications made accessible in the public portal are retained by the authors and/or other copyright owners and it is a condition of accessing publications that users recognise and abide by the legal requirements associated with these

- Users may download and print one copy of any publication from the public portal for the purpose of private study or research.

- You may not further distribute the material or use it for any profit-making activity or commercial gain

If the publication is distributed under the terms of Article $25 \mathrm{fa}$ of the Dutch Copyright Act, indicated by the "Taverne" license above, 


\section{De doorstroom van het initieel naar het niet-initieel onderwijs}

ROA-W-1999/3

Andries de Grip en Ank Jacobs

Researchcentrum voor Onderwijs en Arbeidsmarkt

Faculteit der Economische Wetenschappen en Bedrijfskunde

Universiteit Maastricht

Maastricht, mei 1999 


\section{Inhoud}

Bladzijde

Voorwoord

1 Inleiding

2 Methodiek van instroomprognoses 4

2.1 Inleiding 4

2.2 Methodiek instroom van schoolverlaters op de arbeidsmarkt 4

$\begin{array}{ll}2.3 \text { De Onderwijsrekeningen } & 7\end{array}$

3 Betrouwbaarheid van verschillende databronnen 9

3.1 Inleiding 9

3.2 Het 7-maanden versus het 9-maanden bestand 9

3.3 Aantal waarnemingsjaren 12

4 Gewijzigde samenstelling van arbeidsaanbod als gevolg van uitstroom $\begin{array}{ll}\text { uit niet-initieel onderwijs } & 13\end{array}$

4.1 Inleiding 13

4.2 Niet-initieel onderwijs uitgesplitst 14

5 Niet-initieel onderwijs en de vervangingsvraag per opleidingstype 22

5.1 Inleiding $\quad 22$

5.2 De vervangingsvraag 23

$\begin{array}{ll}5.3 \text { Stroompatronen bij de vervangingsvraag } & 25\end{array}$

6 Samenvatting en conclusie 29

$\begin{array}{ll}\text { Literatuur } & 30\end{array}$

$\begin{array}{ll}\text { Bijlage } 1 & 31\end{array}$

$\begin{array}{ll}\text { Bijlage } 2 & 33\end{array}$

$\begin{array}{ll}\text { Bijlage } 3 & 35\end{array}$ 


\section{Voorwoord}

Dit werkdocument maakt deel uit van het Project Onderwijs Arbeidsmarkt (POA). Dit project wordt gefinancierd door het Ministerie van Onderwijs, Cultuur en Wetenschappen, Arbeidsvoorziening Facilitair Bedrijf, het LDC Expertisecentrum voor Loopbaanvraagstukken en het Ministerie van Landbouw, Natuurbeheer en Visserij.

Om de toekomstige vraag en aanbod op de arbeidsmarkt adequaat met elkaar te kunnen confronteren is het cruciaal dat aan de aanbodkant van de arbeidsmarkt naast de arbeidsmarktinstroom vanuit het initieel voltijd onderwijs ook andere niveau-verhogende of opleidingsrichting-veranderende niet-initiële scholingsactiviteiten van de beroepsbevolking in kaart worden gebracht. In dit werkdocument wordt beoogd nader inzicht te verkrijgen in het effect van het niet-initiële onderwijs op het niveau en de richting van de opleidingsachtergrond van nieuwkomers op de arbeidsmarkt. Bovendien zal het gebruik en de betrouwbaarheid van de verschillende databestanden die beschikbaar zijn vanuit de Onderwijsrekeningen van het $\mathrm{CBS}$ worden geanalyseerd. 


\section{Inleiding}

In het kader van het Project Onderwijs en Arbeidsmarkt (POA) worden elke twee jaar middellange-termijn arbeidsmarktprognoses naar beroepsklasse en opleidingstype opgesteld. De meest recente prognoses hebben betrekking op de periode 1997-2002 (ROA, 1997). Om vraag en aanbod op de arbeidsmarkt adequaat met elkaar te kunnen confronteren is het cruciaal dat aan de aanbodkant naast de arbeidsmarktinstroom vanuit het initiële voltijd onderwijs (stap 1 van de instroomprognose) ook andere niveau-verhogende of opleidingsrichting veranderende scholingsactiviteiten (het niet-initieel onderwijs) van de beroepsbevolking in kaart worden gebracht (stap 2 van de instroomprognose).

De prognose van de arbeidsmarktinstroom vanuit het initiële voltijd onderwijs (stap 1) is gebaseerd op de Referentieraming van het Ministerie van Onderwijs, Cultuur en Wetenschappen. Met deze prognose ligt de totale instroom van nieuwkomers op de arbeidsmarkt vast ${ }^{1}$. In stap 2 wordt de arbeidsmarktinstroom bijgesteld door rekening te houden met de doorstroom naar het niet-initiële onderwijs. Een dergelijke verschuiving van de opleidingsachtergrond van het arbeidsaanbod vindt plaats als iemand een niet-initiële opleiding voltooit die op een hoger niveau ligt of betrekking heeft op een andere opleidingsrichting dan de opleiding die men eerder in het initieel onderwijs heeft voltooid.

Reeds eerder is onderzocht in hoeverre de Onderwijsrekeningen van het CBS mogelijkheden bieden om de kwaliteit van de arbeidsmarktinstroomprognoses vanuit het niet-initieel onderwijs te verbeteren (Matheeuwsen en De Grip, 1997). Uit dit onderzoek komt naar voren dat de Onderwijsrekeningen in het algemeen goede mogelijkheden bieden om de kwaliteit van de prognoses van de arbeidsmarktinstroom vanuit het niet-initieel onderwijs te verbeteren (Matheeuwsen en De Grip, 1997).

De gegevens waarop de instroomprognoses vanuit het niet-initieel onderwijs voor de periode 1997-2002 in het rapport De arbeidsmarkt naar opleiding en beroep tot 2002 (ROA, 1997) zijn gebaseerd, zijn afkomstig uit de Onderwijsrekeningen 1995/1996. Echter bij de gegevens die voor deze instroomprognoses worden verzameld doet zich een probleem voor. De betrouwbaarheid van deze gegevens is wellicht (aanzienlijk) lager dan de betrouwbaarheid van de gegevens waarop de prognoses van de arbeidsmarktinstroom vanuit het initieel onderwijs zijn gebaseerd. Bovendien is bij de prognoses voor de periode 1997-2002 (zie ROA, 1997) slechts gebruik gemaakt van één waarnemingsjaar, wat de betrouwbaarheid van de gegevens mogelijk niet ten goede komt. Bovendien zijn deze gegevens gebaseerd op de Enquête Beroepsbevolking (EBB) over een waarnemingsperiode van slechts zeven maanden. Er kan gebruik worden gemaakt van een bestand met negen waarnemingsmaanden, echter dit bestand is minder recent.

1. Bij de vervangingsvraag wordt impliciet rekening gehouden met de arbeidsmarktinstroom van herintreders. 
In dit werkdocument zal het gebruik en de betrouwbaarheid van de verschillende databestanden die beschikbaar zijn vanuit de Onderwijsrekeningen van het CBS worden geanalyseerd. Bovendien wordt beoogd nader inzicht te verkrijgen in het effect van het niet-initieel onderwijs op het niveau en de richting van de opleidingsachtergrond van nieuwkomers op de arbeidsmarkt. Er zal een vijftal analyses worden verricht:

1. Voor de arbeidsmarktinstroomprognoses kan gebruik worden gemaakt van een 7maanden bestand en een 9-maanden bestand van de Onderwijsrekeningen. Beide bestanden verschillen overigens niet in de periode waarin de scholingsparticipatie wordt getraceerd: bij beide bestanden is dit het voorgaande kalenderjaar. Echter, het 7maanden bestand is gebaseerd op de EBB, afgenomen in de maanden september tot en met maart, terwijl het 9-maanden bestand gebaseerd is op de EBB, afgenomen in de maanden september tot en met $\mathrm{mei}^{2}$. Dit laatst genoemde bestand bevat weliswaar meer waarnemingen, doch daar staat tegenover dat het eerst genoemde bestand in de praktijk eerder beschikbaar is, waardoor met meer recente informatie kan worden gewerkt. De vraag kan nu gesteld worden in hoeverre het recente 7-maanden bestand voldoende betrouwbare gegevens bevat, of dat er beter gebruik kan worden gemaakt van het minder recente 9-maanden bestand, dat een groter aantal waarnemingen bevat.

2. Bij de prognoses van de arbeidsmarktinstroom vanuit het niet-initieel onderwijs op basis van de Onderwijsrekeningen van het CBS, doet zich een tweede keuzeprobleem voor. Er kan gebruik worden gemaakt van één waarnemingsjaar of van het gemiddelde van meerdere jaren. Hierbij gaat het om de afweging tussen de grotere meetfout bij het gebruik van de cijfers van één waarnemingsjaar en de onder- of overschatting van de actuele scholingsparticipatie indien gebruik wordt gemaakt van meerjaarlijkse gemiddelden. Bij het gebruik van meerdere jaren worden bepaalde trendmatige ontwikkelingen immers onderschat. Echter indien tussen de verschillende jaren grote fluctuaties worden waargenomen in de aantallen gediplomeerden in het niet-initieel onderwijs is het wenselijk om bij de instroomprognoses vanuit dit niet-initieel onderwijs gebruik te maken van meerjaarlijkse gemiddelden in plaats van de instabiele jaarcijfers.

De twee hierboven beschreven analyses hebben betrekking op de betrouwbaarheid van de databronnen. De volgende analyses spitsen zich toe op de meer inhoudelijke kant van de kwaliteit van de arbeidsmarktinstroomprognoses vanuit het niet-initieel onderwijs op basis van de Onderwijsrekeningen.

3. De vraag op welke wijze het volgen van niet-initieel onderwijs het kwalificatieprofiel van degene die dit onderwijs voltooit verandert en op welke beroepsgroepen deze om- of bijscholing betrekking heeft, is tot nu toe onvoldoende beantwoord. Een dergelijke analyse kan dan ook nader inzicht verschaffen in de aard van het richting-veranderende dan wel niveau-verhogende effect van het niet-initieel onderwijs. Daarbij wordt ook de werkloze beroepsbevolking meegenomen.

2. Dit 9-maanden bestand wordt in de Onderwijsrekeningen beschouwd als de jaarciffers (zie paragraaf 4.2). 
4. Verder kan een analyse die zich toespitst op de leeftijdsopbouw van de participanten in het niet-initieel onderwijs op een meer indirecte wijze inzicht verschaffen in de aard van dit onderwijs.

5. Ten slotte vraagt de relatie tussen de vervangingvraag per opleidingstype en de deelname aan het niet-initieel onderwijs een nadere beschouwing. Hierbij gaat het met name om de leeftijdsgrens waarop de verandering van iemands opleidingsachtergrond bij de vervangingsvraag reeds wordt meegenomen bij het bepalen van de uitstroom van werkenden met een bepaalde opleidingsachtergrond.

Voor de toepassing van bovengenoemde analyses zal gebruik worden gemaakt van meerdere bestanden afkomstig uit verschillende Onderwijsrekeningen. Het betreft hier de vijf bestanden die betrekking hebben op OR '95/'96 en de OR '96/'97:

1. waarnemingsjaar 1994 uit OR '95/'96, een 7-maanden bestand;

2. waarnemingsjaar 1993 uit OR '95/'96, een 9-maanden bestand;

3. waarnemingsjaar 1994 uit OR '95/'96, een 9-maanden bestand;

4. waarnemingsjaar 1994 uit OR '96/'97, een 7-maanden bestand;

5. waarnemingsjaar 1995 uit OR '96/'97, een 7-maanden bestand ${ }^{3}$.

In tegenstelling tot Matheeuwsen en De Grip (1997) zal bij de analyse van het niveauverhogende of richting-veranderende karakter van het niet-initieel onderwijs de participatie in de Beroeps Begeleidende Leerweg (de vroegere Leerlingwezenopleidingen), buiten beschouwing blijven. Bij de opleidingen in het kader van de Beroeps Begeleidende Leerweg $(\mathrm{BBL})$ is immers sprake van initieel onderwijs. Deze worden derhalve reeds meegenomen in de prognose van de arbeidsmarktinstroom vanuit het initiële onderwijs op basis van de Referentieraming van het Ministerie van OC \& W.

Bij de tabellen in dit werkdocument wordt altijd het aantal gediplomeerden in het niet-initieel onderwijs weergegeven die een niveau-verhogende dan wel richting-veranderende opleiding hebben voltooid. Alleen de richting-veranderende en niveau-verhogende opleidingen zijn immers van invloed op het kwalificatieprofiel van de arbeidsmarktinstroom.

Bij het in beeld brengen van het effect van het gevolgde niet-initieel onderwijs op de opleidingsachtergrond van het arbeidsaanbod, ontstaat het gevaar van dubbeltellingen, omdat bij de vervangingsvraagprognoses reeds (impliciet) rekening wordt gehouden met de 'doorstroom' van werkenden tussen de diverse opleidingstypen. Om die reden dient er een leeftijdsgrens te worden gehanteerd, waarboven de verandering van het kwalificatieprofiel van de werkenden vanwege het afronden van een niet-initiële opleiding niet meer wordt meegenomen. $\mathrm{Er}$ is gekozen voor een leeftijdsgrens van 40 jaar, omdat boven deze leeftijdsgrens het voltooien van een niveau-verhogende dan wel richting-veranderende

3. Zoals reeds eerder is opgemerkt, beslaan al deze verschillende bestanden een periode van één kalenderjaar. 
niet-initiële opleiding in vrijwel alle gevallen reeds wordt meegenomen bij de prognoses van de vervangingsvraag ${ }^{4}$.

Dit werkdocument is als volgt opgebouwd. In hoofdstuk 2 wordt een korte samenvatting gegeven van de methodiek van de arbeidsmarktinstroomprognoses vanuit het niet-initieel onderwijs en van het gebruik van de Onderwijsrekeningen. Vervolgens komen in hoofdstuk 3 de eerder genoemde analyses met betrekking tot de betrouwbaarheid van de verschillende databronnen en de verschillende waarnemingsjaren, aan bod. In hoofdstuk 4 staan de analyses met betrekking tot de meer inhoudelijke kant van de arbeidsmarktinstroomprognoses vanuit het niet-initiële onderwijs centraal. Hierbij komen de vooropleidingen, de leeftijdsopbouw, de positie op de arbeidsmarkt, etc. van de participanten in het niet-initieel onderwijs aan de orde. Hoofdstuk 5 stelt de relatie tussen het volgen van niet-initieel onderwijs en de vervangingsvraag nader aan de orde. Ten slotte worden in hoofdstuk 6 de bevindingen uit de verrichte analyses kort samengevat en worden enkele conclusies getrokken met betrekking tot de te gebruiken databestanden voor de arbeidsmarktinstroomprognoses vanuit het niet-initieel onderwijs.

\section{Methodiek van instroomprognoses}

\subsection{Inleiding}

In dit hoofdstuk wordt de methodiek om arbeidsmarktinstroomprognoses vanuit het nietinitieel onderwijs op te stellen en de rol die de Onderwijsrekeningen hierbij spelen, kort beschreven. Paragraaf 2.2 behandelt de methodiek van de instroomprognoses vanuit het niet-initieel onderwijs. Vervolgens wordt in paragraaf 2.3 ingegaan op de relevantie van de Onderwijsrekeningen voor de instroomprognoses. Ten slotte worden in deze paragraaf de criteria weergegeven waaraan de gediplomeerden van en de niet-initiële opleidingen aan moeten voldoen indien een opleiding als niet-initieel wordt aangemerkt.

\subsection{Methodiek instroom van schoolverlaters op de arbeidsmarkt ${ }^{5}$}

Figuur 2.1 geeft een schematisch overzicht van de opbouw van de instroomprognose. In het prognosemodel worden globaal gesproken twee stappen onderscheiden. In de eerste stap wordt de prognose opgesteld van de verwachte toekomstige uitstroom uit het initiële voltijd onderwijs ${ }^{6}$. Niet voor alle schoolverlaters eindigt na het verlaten van het initiële voltijd onderwijs de schoolloopbaan. Na het verlaten van het initieel voltijd onderwijs kan men

4. In hoofdstuk 5 zal hierop verder worden ingegaan. De in hoofdstuk 4 gepresenteerde tabellen hebben overigens nog betrekking op alle leeftijdsgroepen.

5. Deze paragraaf is gebaseerd op Borghans et al., 1997.

6. Een nadere beschrijving van deze stap is te vinden in Matheeuwsen en De Grip (1997) en Borghans et al. (1997). 
immers doorstromen naar het deeltijd onderwijs, het niet-initiële voltijd onderwijs en het beroepsgerichte volwassenenonderwijs. Als men daar een diploma behaalt én de gevolgde opleiding ligt op een hoger niveau of een andere richting dan de vooropleiding, dan moet de instroomprognose worden bijgesteld. Deze bijstelling vindt plaats in stap 2.

Deze bijstelling van de uitstroom uit het initiële voltijd onderwijs vereist niet alleen data over het aantal gediplomeerden dat uitstroomt uit de initiële deeltijd-, de niet-initiële en de volwassenenopleidingen naar de arbeidsmarkt, maar ook informatie over de vooropleiding van deze gediplomeerden.

Het belangrijkste verschil tussen de methodiek die is gehanteerd bij de arbeidsmarktinstroomprognoses voor de periode 1997-2002 en de aanpak die daarvoor werd gevolgd is de verandering van de databronnen. Voorheen werden de gegevens samengesteld uit een groot aantal verschillende databronnen. Bij de meest recente prognoses zijn er voornamelijk twee grote databronnen geraadpleegd. Dit bevordert de uniformiteit van de data en voorkomt mogelijke dubbeltellingen. Voor de uitstroom uit de Beroeps Begeleidende Leerweg is gebruik gemaakt van de prognoses van het aantal schoolverlaters uit het primaire en secundaire leerlingwezen uit de Referentieraming 1997. Deze aantallen zijn verbijzonderd naar opleidingstype aan de hand van gegevens over het leerlingwezen uit de Onderwijsrekeningen. Deze databron leverde tevens de aantallen voor het niet-initieel onderwijs (Matheeuwsen en De Grip, 1997).

$\mathrm{Na}$ de bijstelling in stap 2 van de uitstroom uit het initiële voltijd onderwijs resulteerde de toekomstige instroom van schoolverlaters op de arbeidsmarkt per ROA-opleidingstype voor de prognoseperiode 1997-2002. 
Figuur 2.1

Globaal schema ter bepaling van de verwachte toekomstige instroom van schoolverlaters op de arbeidsmarkt naar ROA-opleidingstype

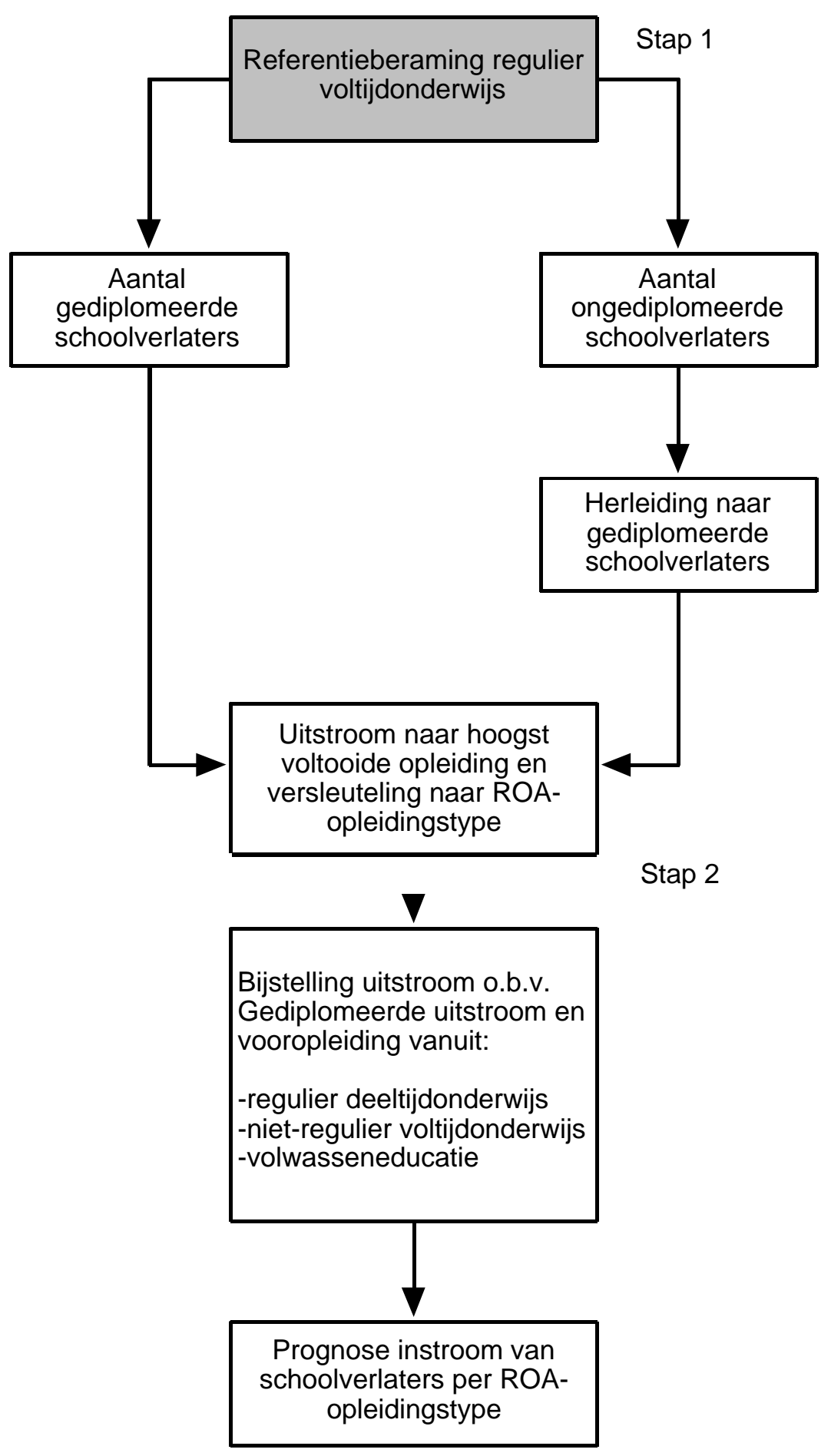




\subsection{De Onderwijsrekeningen ${ }^{7}$}

In de Onderwijsrekeningen zijn twee kernvariabelen opgenomen die betrekking hebben op de onderwijsachtergrond van de respondenten:

$\mathrm{C}$ de opleiding die men op moment van enquêteren volgt (de actuele opleiding);

$C$ de gevolgde opleidingen.

Met de variabelen die betrekking hebben op de actuele opleiding worden verschillende kenmerken gemeten die behoren bij de opleiding die de respondent op het moment van enquêteren volgt. Op basis van deze informatie wordt het aantal onderwijsvolgenden in een bepaald schooljaar vastgesteld. In de Onderwijsrekeningen worden alleen die personen meegeteld die een opleiding met een opleidingsduur van ten minste zes maanden volgen.

Van de actuele opleiding, de opleiding die men op het moment van enquêteren volgt, is echter niet bekend of men deze opleiding met succes zal afronden. Eveneens is niet bekend of er sprake zal zijn van een verandering van het kwalificatieprofiel, met andere woorden: de mate waarin het behalen van de actuele opleiding de hoogst behaalde opleiding verandert of de mate waarin de actuele opleiding de opleidingsrichting verandert. Er zullen dus veronderstellingen moeten worden gemaakt over het slagingspercentage en de mate waarin het kwalificatieprofiel zal veranderen, veronderstellingen die ook in de huidige methodiek van de arbeidsmarktinstroomprognoses worden gemaakt. De gegevens over de actuele opleiding van de respondenten geven derhalve niet de benodigde gegevens om het niveau-verhogende of opleidingsrichting-veranderende karakter van de niet-initiële opleiding te bepalen.

De gegevens met betrekking tot de gevolgde opleidingen die aan de EBB worden ontleend bieden duidelijk meer mogelijkheden. Aan de respondenten wordt gevraagd welke opleidingen met een opleidingsduur van meer dan zes maanden zij na het basisonderwijs hebben gevolgd. En van deze opleidingen (maximaal 6) wordt onder andere eveneens gevraagd:

$\mathrm{C}$ wanneer men met de opleiding is begonnen;

$C$ wanneer men de opleiding heeft beëindigd;

$\mathrm{C}$ de duur van de opleiding;

$\mathrm{C}$ of men de opleiding in deeltijd of voltijd heeft gevolgd;

$\mathrm{C}$ of men de opleiding met diploma heeft afgerond;

$C$ de naam van de (soort) opleiding.

Op basis van de naam van de opleiding wordt zowel de SOl-5-digit code als het identificatienummer bepaald die bij de opleiding behoren. De SOI-5-digit code is een 5 cijferige opleidingscode, waarbij soortgelijke opleidingen dezelfde code krijgen. Daarnaast krijgt iedere opleiding een uniek identificatienummer. Op basis van de SOI-5-digit code en

7. Deze paragraaf is gebaseerd op Matheeuwsen en De Grip, 1997. 
het identificatienummer kan iedere opleiding op het laagst mogelijke aggregatieniveau worden gecodeerd. Het verder verbijzonderen van de SOI-5-digit indeling op basis van de identificatienummers heeft het grote voordeel dat de opleidingen van de BBL onderscheiden kunnen worden van de verwante initiële MBO-opleidingen.

Naast de informatie over de gevolgde opleidingen wordt gebruik gemaakt van de gegevens over de hoogst behaalde opleiding van de respondenten. Deze hoogst behaalde opleiding wordt bepaald op basis van de gevolgde opleidingen van de respondenten. De informatie die idealiter beschikbaar zou moeten zijn over de gevolgde niet-initiële opleiding is op basis van bovenstaande aspecten van de gevolgde opleidingen te bepalen ${ }^{8}$ :

$\mathrm{C}$ het opleidingstype waartoe de opleiding gerekend kan worden: SOI-5-digit code en identificatienummer;

$\mathrm{C}$ het behalen van het diploma;

$\mathrm{C}$ de vooropleiding;

$\mathrm{C}$ of er sprake is van een verandering van het kwalificatieprofiel: vergelijking (hoogst behaalde) vooropleiding en de gevolgde opleiding.

Van de gevolgde opleiding is echter niet bekend of deze opleiding een initiële voltijd opleiding of een niet-initiële opleiding is. In de Onderwijsrekeningen dient het initiële voltijd onderwijs van het niet-initiële onderwijs te worden afgebakend. Allereerst zijn hiervoor de BBL-opleidingen op basis van het identificatienummer geselecteerd. Deze opleidingen zijn vervolgens buiten beschouwing gelaten, omdat ze in stap 1 reeds zijn meegenomen. Het niet-initiële onderwijs is vervolgens afgebakend van het initiële voltijd onderwijs op basis van een geamendeerd afleidingsschema van het CBS. Een opleiding op het desbetreffende opleidingsniveau is getypeerd als een initiële voltijd opleiding als de gediplomeerden aan de voorwaarden voldoen die in tabel 2.1 worden gegeven. Indien dat niet het geval is, wordt een opleiding als niet-initieel gedefinieerd.

Op één punt wordt echter van de door het CBS gehanteerde afbakening afgeweken. Een opleiding op WO-niveau wordt door het CBS als een voltijd opleiding beschouwd, als de leeftijd van de student tussen de 22 en 65 jaar ligt en de opleidingsduur van de studie 4 jaar of meer is. Ons inziens heeft dit als nadeel dat bijvoorbeeld de geslaagden van de Open Universiteit en de NIVRA-opleidingen ten onrechte tot de gediplomeerden van het initiële voltijd onderwijs worden gerekend. Voor dit onderzoek wordt een WO-opleiding daarom dan ook als voltijd opleiding gedefinieerd als de leeftijd van de student tussen de 22 en 31 jaar ligt en de opleidingsduur 4 jaar of meer is. Door de leeftijdscategorie te beperken tot de afgestudeerden van 22 tot 31 jaar behoren 3.000 geslaagde voltijders volgens de CBS-afbakening, in dit onderzoek tot het niet-initiële onderwijs.

8. De gegevens die voor dit onderzoek worden gebruikt zijn in feite afkomstig uit de EBB. Omdat door ons gebruik is gemaakt van het bestand van de Onderwijsrekeningen zal toch steeds bij de bronverwijzing van Onderwijsrekeningen worden gesproken in plaats van EBB. 
Tabel 2.1

Voorwaarden waaraan moet worden voldaan om een opleiding als initiële voltijd opleiding te definiëren (leeftijd op moment van behalen diploma en opleidingsduur)

$\begin{array}{ll}\text { MAVO } & \# 19 \text { jaar } \\ \text { VBO } & \# 20 \text { jaar } \\ \text { HAVO } & \# 19 \text { jaar } \\ \text { VWO } & \# 20 \text { jaar } \\ \text { MBO } & <24 \text { jaar en opleidingsduur } \$ 3 \text { jaar } \\ \text { HBO } & \$ 21 \text { en }<30 \text { jaar en opleidingsduur } \$ 3 \text { jaar } \\ \text { WO } & \$ 22 \text { en } \# 30 \text { jaar en opleidingsduur } \$ 4 \text { jaar }\end{array}$

Bron: ROA/CBS

Op deze wijze resulteren de gevolgde niet-initiële opleidingen. Vervolgens worden de nietinitiële opleidingen die men met goed gevolg heeft voltooid geselecteerd. Op basis van het jaar waarin men de opleiding heeft voltooid, wordt het aantal gediplomeerden van de nietinitiële opleidingen in het desbetreffende jaar bepaald.

\section{Betrouwbaarheid van verschillende databronnen}

\subsection{Inleiding}

In dit hoofdstuk komen de analyses met betrekking tot de betrouwbaarheid van verschillende databronnen en de betrouwbaarheid van verschillende waarnemingsperioden, aan bod. Paragraaf 3.2 analyseert het verschil tussen het 7-maanden en het 9-maanden bestand. Vervolgens gaat paragraaf 3.3 in op de betrouwbaarheid van de cijfers uit één waarnemingsjaar in vergelijking met de cijfers uit meerdere waarnemingsjaren.

\subsection{Het 7-maanden versus het 9-maanden bestand}

De Onderwijsrekeningen van het CBS hebben, zoals reeds eerder is aangegeven, slechts een waarnemingsperiode van negen maanden hoewel de EBB, waarop de gegevens uit de Onderwijsrekeningen zijn gebaseerd, een heel kalenderjaar beslaan. Deze periode van slechts negen maanden is echter bewust gekozen om de vakantiemaanden, te weten juni, juli en augustus, buiten de waarnemingsperiode te houden. In deze vakantiemaanden hebben immers veel scholieren en studenten vakantiebaantjes, waardoor ze tot de werkenden worden gerekend. Indien deze scholieren en studenten in die maanden worden geënquêteerd kan dat verkeerde informatie over de scholingsparticipatie van werkenden opleveren.

De informatie over de meest recente Onderwijsrekeningen komt eerst beschikbaar in de vorm van een 7-maanden bestand en wordt pas later aangevuld met de resterende twee 
waarnemingsmaanden. Daardoor moet vaak gekozen worden tussen het gebruik van de meest recente informatie gebaseerd op zeven waarnemingsmaanden of het gebruik van het beschikbare 9-maanden bestand van de Onderwijsrekeningen van het voorgaande jaar. In deze paragraaf zal worden ingegaan op de vraag in hoeverre de betrouwbaarheid van de instroomprognoses kan worden vergroot door de waarnemingsperiode te vergroten van zeven naar negen maanden. Indien dit de betrouwbaarheid niet noemenswaardig vergroot, kan er gebruik worden gemaakt van de meer recente 7-maanden gegevens in plaats van de minder recente 9-maanden gegevens van de Onderwijsrekeningen van het voorgaande jaar.

Uit de OR 1995/1996 zijn voor het jaar 1994 twee bestanden beschikbaar: een 7-maanden bestand en een 9-maanden bestand. Om de betrouwbaarheid van het 7-maanden bestand te bestuderen wordt er een zogenoemde onbetrouwbaarheidsfactor berekend die aangeeft hoe groot de afwijking tussen het 7-maanden en het 9-maanden bestand is, waarbij het 9maanden bestand als referentiebestand dient.

Bovengenoemde onbetrouwbaarheidsfactor is als volgt gedefinieerd:

$$
\text { onbetrouwbaarheidsfactor }=\frac{A B S\left(a_{i 1}-a_{i 3}\right)}{a_{i 3}}
$$

Waarbij:

$\mathrm{a}_{\mathrm{i1}}=$ waarneming opleidingstype i voor 1994, op basis van OR '95/'96, dit betreft het 7maanden bestand;

$\mathrm{a}_{\mathrm{i} 3}=$ waarneming opleidingstype i voor 1994, op basis van OR '95/'96, dit betreft het 9maanden bestand.

Deze onbetrouwbaarheidsfactor impliceert dat hoe groter de waarde van deze factor is, hoe meer het 7-maanden bestand afwijkt van het 9-maanden bestand. Omdat hierboven het 9-maanden bestand vanwege het grotere aantal waarnemingen als het meest betrouwbare bestand wordt beschouwd, gaan we ervan uit dat hoe groter de factor is hoe minder betrouwbaar het 7-maanden bestand is.

Tabel 3.1 geeft een overzicht van de onbetrouwbaarheidsfactoren van de informatie over de voltooide niet-initiële opleidingen verbijzonderd naar opleidingsniveau. Als eerste is de onbetrouwbaarheidsfactor per opleidingstype berekend. Deze factoren zijn daarna per opleidingsniveau gemiddeld. Uit de tabel blijkt dat de afwijkingen van het 7-maanden bestand ten opzichte van het 9-maanden bestand aanzienlijk zijn. De betrouwbaarheid van de 7-maanden cijfers is het grootst voor de opleidingsniveaus MBO, HAVO/VWO en (Post-) $W^{9}$. Voor het opleidingsniveau VBO, MAVO is de afwijking tussen de EBB-bestanden

9. Het MBO, HAVO/VWO zal hieronder telkens met de verkorte naam MBO worden aangeduid en het (Post-)WO met de verkorte naam WO. 
over zeven en negen maanden het grootst. De betrouwbaarheid voor het HBO ligt hier tussen in. Een mogelijke verklaring voor de grotere betrouwbaarheid voor het MBO is het grote aantal personen dat niet-initiële opleidingen op dit niveau volgt.

Tabel 3.1

Onbetrouwbaarheidsfactor 7-maanden bestand van de waargenomen niet-initiële opleidingen per opleidingsniveau

Opleidingsniveau

onbetrouwbaarheidsfactor

$\begin{array}{ll}\text { VBO, MAVO } & 0,23 \\ \text { MBO, HAVO/VWO } & 0,15 \\ \text { HBO } & 0,18 \\ \text { (Post-)WO } & 0,15\end{array}$

Bron: ROA/CBS

Als verder gekeken wordt naar de richting van de afwijkingen tussen beide bestanden, kan geconcludeerd worden dat het 7-maanden bestand ten opzichte van het 9-maanden bestand in het algemeen een overschatting van het voltooide niet-initiële onderwijs laat zien. Bijlage 1 geeft een gedetailleerd overzicht van de onderschatting naar opleidingstype.

Uit dit overzicht kan het volgende worden geconcludeerd:

C Op VBO, MAVO niveau wordt op basis van de 7-maanden cijfers bij twee opleidingsrichtingen de scholingsparticipatie onderschat, bij de andere opleidingstypen kan een overschatting worden geconstateerd.

C Op MBO niveau wordt op basis van de 7-maanden cijfers bij dertien opleidingsrichtingen de scholingsparticipatie onderschat, bij de rest wordt een overschatting geconstateerd.

C Op HBO niveau wordt op basis van de 7-maanden cijfers bij acht opleidingstypen een onderschatting van de scholingsparticipatie geconstateerd, bij de andere opleidingsrichtingen wordt een overschatting vastgesteld.

C Op WO niveau wordt op basis van de 7-maanden cijfers slechts bij twee opleidingsrichtingen een onderschatting van de scholingsparticipatie vastgesteld, bij de overige opleidingsrichtingen wordt een overschatting geconstateerd.

Vervolgens is de onbetrouwbaarheidsfactor in relatie tot de omvang van de niveauverhogende of richting-veranderende niet-initiële opleidingen berekend. Hierbij zijn de 113 verschillende opleidingstypen onderverdeeld naar het aantal waarnemingen van de gevolgde niveau-verhogende of richting-veranderende niet-initiële opleidingen (zie tabel $3.2)$.

Tabel 3.2

Onbetrouwbaarheidsfactor 7-maanden bestand per grootteklasse

Aantal waarnemingen van participatie in 
Bron: ROA/CBS

Uit de tabel is af te lezen dat de klassen met het grootste aantal waarnemingen van scholingsparticipatie in het niet-initiële onderwijs, het meest betrouwbaar zijn. De klasse tot 300 waarnemingen is hier echter een uitzondering op.

In het algemeen kan geconcludeerd worden dat de mate van overschatting van de niveauverhogende of richting-veranderende scholingsparticipatie in het 7-maanden bestand groter is naarmate het aantal waarnemingen afneemt.

Samenvattend kan gesteld worden dat de verschillen tussen de waargenomen niet-initiële opleidingen in het 7- en 9-maanden bestand aanzienlijk zijn. Dit betekent dat de 9maanden cijfers een meer betrouwbaar beeld geven van het aantal participanten in het niet-initiële onderwijs. De grotere actualiteit van de data uit het 7-maanden bestand weegt derhalve niet op tegen de grotere betrouwbaarheid van de data uit het 9-maanden bestand.

\subsection{Aantal waarnemingsjaren}

Bij De Arbeidsmarkt naar opleiding en beroep tot 2002 is bij de arbeidsmarktinstroomprognoses het opleidingsniveau-verhogende of -richting-veranderende niet-initieel onderwijs slechts geïndiceerd op basis van de gegevens uit één waarnemingsjaar. Daarbij kan de vraag worden gesteld of het niet meer verantwoord is in plaats van de meest recente jaarcijfers gebruik te maken van een meerjaarlijks gemiddelde. Hierbij gaat het in feite om de afweging tussen de grotere meetfout bij het gebruik van de cijfers van één waarnemingsjaar en de onder- of overschatting van de actuele scholingsparticipatie wanneer gebruik wordt gemaakt van meerjaarlijkse gemiddelden.

Om te bepalen of bij het opstellen van de instroomprognoses van schoolverlaters op de arbeidsmarkt het beste gebruik kan worden gemaakt van één of meerdere waarnemingsjaren is gekeken naar de verschillen tussen de (9-maanden bestanden van de) waarnemingsjaren 1993 en 1994 uit de OR '95/'96'10. Voor een aantal opleidingstypen zijn deze verschillen tussen beide jaren behoorlijk groot. Deze verschillen zijn bij veel

10. Een vergelijking tussen meerdere waarnemingsjaren was op basis van de beschikbare 9-maanden bestanden niet mogelijk. 
opleidingstypen waarschijnlijk groter dan op basis van de feitelijke jaarlijkse fluctuaties verwacht zou mogen worden. Zo blijkt er bijvoorbeeld bij het opleidingstype $M B O$ administratie een verschil van 5.000 gediplomeerden te zijn in twee opeenvolgende jaren: in 199313.000 gediplomeerden en in 1994 circa 8.000 gediplomeerden.

Omdat geen cijfers mogen worden gepubliceerd die betrekking hebben op minder dan 2.500 werkenden mogen de meeste aantallen gediplomeerden niet gepubliceerd worden. Daardoor is het niet mogelijk om hier in een tabel een overzicht te geven van de verschillen.

Wanneer de cijfers van beide jaren worden geaggregeerd naar opleidingssector of opleidingsniveau zijn de afwijkingen tussen de aantallen gediplomeerden van het jaar '93 en '94 daarentegen minimaal. Dit duidt op substantiële waarnemingsfouten bij de jaarcijfers per opleidingstype die veel grotere fluctuaties laten zien. Omdat de arbeidsmarktinstroomprognoses per opleidingstype worden opgesteld is het derhalve wenselijk bij de prognose van het opleidingsniveau-verhogende en -richting-veranderende karakter van het niet-initieel onderwijs gebruik te maken van meerjaarlijkse gemiddelden van de cijfers uit de Onderwijsrekeningen.

\section{Gewijzigde samenstelling van arbeidsaanbod als gevolg van uitstroom uit niet-initieel onderwijs}

\subsection{Inleiding}

In dit hoofdstuk wordt een aantal tabellen gepresenteerd met als doel een nader inzicht te verkrijgen in de niveau-verhogende dan wel opleidingsrichting-veranderende participatie in het niet-initieel onderwijs. In paragraaf 4.2 wordt door middel van een aantal analyses getracht om meer duidelijkheid omtrent deze aard van de scholing te verkrijgen. Hierbij gaat het om de volgende vragen:

C wordt de opleiding in voltijd dan wel in deeltijd gevolgd?

$\mathrm{C}$ in welk leeftijdscohort bevinden de participanten in het niet-initieel onderwijs zich?

$\mathrm{C}$ is het vooral de werkende of werkloze beroepsbevolking die niet-initieel onderwijs volgt?

$C$ in welke beroepsgroep en bedrijfssector wordt relatief veel niet-initieel onderwijs gevolgd? 


\subsection{Niet-initieel onderwijs uitgesplitst}

Om een goed beeld en overzicht te krijgen van het aantal gediplomeerden in het nietinitieel onderwijs in de jaren 1993-1995, zal in de volgende twee tabellen (4.1 en 4.2) het aantal participanten per opleidingsniveau en naar vooropleiding worden weergegeven.

Tabel 4.1

Aantal gediplomeerden niet-initieel onderwijs per opleidingsniveau, 1993, 1994 en 1995

\begin{tabular}{lrrr}
\hline Opleidingsniveau & & aantal studenten \\
& 1993 & $1994^{*}$ & 1995 \\
\hline MAVO & 3.200 & 3.400 & \\
VBO & 30.300 & 30.000 & 28.200 \\
HAVO/ VWO & 6.500 & 9.500 & 7.100 \\
MBO & 139.400 & 130.400 & 121.800 \\
HBO & 39.500 & 36.700 & 39.900 \\
WO & 8.600 & 9.400 & 10.400 \\
Totaal & 227.700 & 219.500 & 208.300 \\
\hline
\end{tabular}

* Deze gegevens komen uit de OR '95/'96 om reeds eerder genoemde redenen.

. Er wordt niet voldaan aan de ondergrens van publicatie $(<2.500)$.

Bron: ROA/CBS

Tabel 4.2

Aantal gediplomeerden niet-initieel onderwijs per opleidingsniveau naar vooropleiding, gemiddelde 1993-'95

\begin{tabular}{|c|c|c|c|c|c|}
\hline \multirow[t]{2}{*}{ Niveau actuele opleiding } & \multicolumn{4}{|c|}{ niveau vooropleiding } & \multirow[b]{2}{*}{ WO } \\
\hline & $\begin{array}{c}\text { basis- } \\
\text { onderwijs }\end{array}$ & VBO/MAVO & MBO & $\mathrm{HBO}$ & \\
\hline VBO, MAVO & 3.600 & 10.400 & 15.500 & & \\
\hline MBO & 5.500 & 37.700 & 82.000 & 10.800 & \\
\hline $\mathrm{HBO}$ & & & 14.300 & 19.000 & 4.400 \\
\hline (Post-) WO & - & - & & 6.000 & \\
\hline Totaal & 9.300 & 48.900 & 113.300 & 37.800 & 9.100 \\
\hline
\end{tabular}

. $\quad$ Er wordt niet voldaan aan de ondergrens van publicatie.

- Nihil.

Bron: ROA/CBS

Op basis van slechts drie waarnemingsjaren is het vanzelfsprekend moeilijk om enige conclusies omtrent trends in het aantal gediplomeerden in het niet-initieel onderwijs te trekken. Uit de hierboven staande tabel volgt dat het aantal studenten dat niet-initieel Voor- 
bereidend Beroepsonderwijs volgt licht afneemt ${ }^{11}$. In dezelfde tabel is te zien dat het aantal studenten dat niet-initieel Middelbaar Beroepsonderwijs volgt eveneens vermindert. In tegenstelling tot de andere opleidingsniveaus is het aantal studenten dat niet-initieel Wetenschappelijk Onderwijs volgt toegenomen. Het totale aantal participanten in het niet-initieel onderwijs is in de jaren 1993-'95 licht gedaald. Het grootste deel van de gediplomeerden in het niet-initieel onderwijs heeft een opleiding voltooid op MBO niveau. In de jaren 1993, 1994 en 1995 schommelt het aandeel van de opleidingen op MBO niveau binnen het nietinitieel onderwijs rond de $63 \%$. Het grootste deel van de participanten in het niet-initieel onderwijs heeft als vooropleiding VBO, MAVO dan wel MBO gevolgd. Relatief bezien schommelt dit aandeel in de weergegeven jaren voor VBO, MAVO en MBO respectievelijk rond de $22 \%$ en $52 \%$. In het algemeen ligt de gevolgde vooropleiding één niveau lager dan de actuele niet-initiële opleiding.

In de volgende tabellen worden telkens de meerjaarlijkse gemiddelden genomen. Uit paragraaf 3.3 kwam reeds naar voren dat dit de meest betrouwbare informatie oplevert over de actuele participatie in het niet-initiële onderwijs.

In tabel 4.3 wordt een overzicht gegeven van het aantal gediplomeerden in het niet-initieel onderwijs per opleidingsniveau per leeftijdscohort.

Tabel 4.3

Aantal gediplomeerden niet-initieel onderwijs per opleidingsniveau naar leeftijdscohort, gemiddelde 1993-'95

Opleidingsniveau

\# 20 leeftijd

$\begin{array}{lrrr}\# 20 & 21-30 & 31-40 & >40^{*} \\ \text { jaar } & \text { jaar } & \text { jaar } & \text { jaar }\end{array}$

\begin{tabular}{llrrr}
\hline & & & & \\
VBO, MAVO & - & 15.300 & 9.300 & 7.400 \\
MBO & 23.400 & 63.900 & 32.700 & 18.300 \\
HBO & - & 12.800 & 15.800 & 8.400 \\
WO & - & 4.000 & 4.000 &.
\end{tabular}

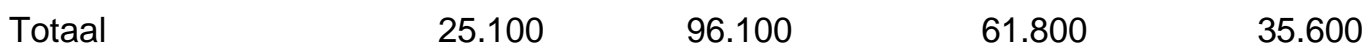

* Het leeftijdscohort $>40$ jaar wordt hier weliswaar gepresenteerd, maar heeft geen invloed meer op een verandering van het kwalificatieprofiel (zie hoofdstuk 5).

. Er wordt niet voldaan aan de ondergrens van publicatie.

- Nihil.

Bron: ROA/CBS

De meeste gediplomeerden in het niet-initieel onderwijs zijn tussen de 21 en 30 jaar oud. Daarvan volgen de meesten een niet-initiële opleiding op MBO-niveau. Van de gediplomeerden in het niet-initieel onderwijs op MBO-niveau die 20 jaar of jonger zijn, kan

11. In de rest van de tabellen wordt VBO en MAVO en BOL en HAVO/ VWO samen gepresenteerd, voor een uitsplitsing per opleidingsniveau wordt verwezen naar bijlage 3 . 
verwacht worden dat zij zich nog niet op de arbeidsmarkt bevinden en dat de gevolgde niet-initiële opleiding een voltijd opleiding betreft ${ }^{12}$.

Tabel 4.4

Aantal gediplomeerden niet-initieel voltijd/deeltijd/onbekend* onderwijs per opleidings-niveau, gemiddelde 1994-'95

\begin{tabular}{lrrr}
\hline Opleidingsniveau & voltijd & deeltijd & onbekend \\
\hline VBO, MAVO & 2.600 & 14.600 & 14.100 \\
MBO & 23.600 & 43.200 & 67.600 \\
HBO & 4.400 & 15.100 & 18.800 \\
WO &. &. & 6.700 \\
Totaal & 32.600 & 74.100 & 107.200
\end{tabular}

\footnotetext{
* Van het jaar 1993 uit de OR '95/'96 is niet bekend of de niet- initiële opleiding in voltijd of in deeltijd wordt gevolgd.

Er wordt niet voldaan aan de ondergrens van publicatie.
}

Bron: ROA/CBS

Tabel 4.5

Aantal gediplomeerden niet-initieel voltijd/deeltijd/onbekend* onderwijs uitgesplitst naar werkend/ werkloos/onbekend, gemiddelde 1994-'95

\begin{tabular}{lrrrr}
\hline & voltijd & deeltijd & onbekend & totaal \\
\hline Werkend & 20.700 & 65.100 & 86.900 & 172.700 \\
Werkloos & 2.900 & 3.400 & 5.700 & 12.000 \\
Onbekend & 9.000 & 5.600 & 14.500 & 29.200 \\
Totaal & 32.600 & 74.100 & 107.200 & 213.900 \\
\hline
\end{tabular}

* Van het jaar 1993 uit de OR '95/'96 is niet bekend of de participanten die een niet-initiële opleiding volgen werkend dan wel werkloos zijn.

Bron: ROA/CBS

Voor het meerjaarlijks gemiddelde geldt dat voor de weergegeven opleidingsniveaus de meeste opleidingen in deeltijd worden gevolgd. Een uitzondering hierop is het WO. De opleidingen op dit niveau worden in het algemeen in voltijd gevolgd. Dit kan overigens een gevolg zijn van de gekozen criteria om het initieel van het niet-initieel onderwijs af te bakenen (zie tabel 2.1).

Uit de tabel blijkt dat ongeveer 22.000 gediplomeerden in het niet-initieel onderwijs een opleiding op MBO-niveau in voltijd hebben gevolgd. Indien de categorie onbekend (voor de

12. Deze opleidingen betreffen waarschijnlijk niet-regulier onderwijs. De afbakening tussen regulier en niet-regulier onderwijs is afhankelijk van de financieringswijze van het onderwijs. 
vraag of gediplomeerde werkend dan wel werkloos is) buiten beschouwing wordt gelaten valt op dat relatief veel werkenden niet-initieel onderwijs hebben gevolgd. Het aantal werkende gediplomeerden als aandeel in de werkzame beroepsbevolking circa $3 \%{ }^{13}$. Dit aandeel kan men als redelijk groot beschouwen omdat het hier om substantiële bij- of omscholing gaat waarbij het kwalificatieprofiel van een werkende aanzienlijk verandert. De meeste gediplomeerden volgden dit niet-initieel onderwijs in deeltijd.

Tabel 4.6

Aantal gediplomeerden niet-initiële onderwijs per beroepsgroep naar opleidingsniveau, gemiddelde 1993-'95

\begin{tabular}{|c|c|c|c|c|c|}
\hline \multirow[t]{2}{*}{ Beroepsgroep } & \multicolumn{5}{|c|}{ niveau actuele opleiding } \\
\hline & /BO/MAVO & MBO & $\mathrm{HBO}$ & WO & totaal \\
\hline Pedagogische beroepen & . & . & 7.300 & . & 10.400 \\
\hline Culturele beroepen & . & & & ${ }^{\circ}$ & 3.200 \\
\hline Agrarische beroepen & & 3.200 & & & 4.900 \\
\hline Technische en industrieberoepen & 4.800 & 24.200 & 2.700 & . & 32.200 \\
\hline Transportberoepen & 2.400 & 2.300 & & . & 5.000 \\
\hline Medische en paramedische beroepen & & 7.000 & 4.800 & & 13.900 \\
\hline $\begin{array}{l}\text { Economisch-administratieve } \\
\text { beroepen }\end{array}$ & 6.800 & 40.800 & 10.600 & 3.600 & 61.800 \\
\hline Informaticaberoepen & . & 3.200 & & . & 5.800 \\
\hline Sociaal-culturele beroepen & . & . & 2.900 & . & 6.900 \\
\hline $\begin{array}{l}\text { Verzorgende en dienstverlenende } \\
\text { beroepen } \\
\text { Openbare orde en veiligheids- }\end{array}$ & 4.400 & 24.000 & & r. & 29.900 \\
\hline beroepen & & 3.200 & & & 4.900 \\
\hline Overig (incl. onbekend) & 8.300 & 24.700 & 4.600 & . & 39.300 \\
\hline Totaal & 32.100 & 138.200 & 38.700 & 9.400 & 218.500 \\
\hline
\end{tabular}

Er wordt niet voldaan aan de ondergrens van publicatie.

Bron: ROA/CBS

Een gegeven dat opvalt in tabel 4.5 is dat er gediplomeerden zijn die een voltijd niet-initiële opleiding hebben gevolgd en tevens werkend waren. Een verklaring hiervoor kan zijn dat de opleiding voor een groot gedeelte uit zelfstudie bestond, de gediplomeerde een deeltijd baan had, of een combinatie van beiden. De volgende tabel geeft het aantal gediplomeerden in het niet-initieel onderwijs aan uitgesplitst naar beroepsgroep en opleidingsniveau.

De participatiegraad per beroepsgroep schommelt tussen 1\% voor de beroepsgroep Transportberoepen en $6 \%$ voor de Verzorgende en dienstverlenende beroepen ${ }^{14}$. In een

13. De categorie onbekend voor de vraag of opleiding in voltijd of deeltijd wordt gevolgd wordt wederom buiten beschouwing gelaten.

14. Voor de berekening van de scholingsparticipatie is het gemiddeld aantal werkenden in 1994-'95 in een bedrijfssector gebruikt (zie ROA, 1996). 
drietal beroepsgroepen, te weten Technische en industrieberoepen, Economisch-administratieve beroepen en Verzorgende en dienstverlenende beroepen is relatief veel nietinitieel onderwijs op MBO niveau gevolgd.

Van de gediplomeerden in het niet-initieel onderwijs op MBO niveau in de drie bovengenoemde beroepsgroepen, behoort het merendeel tot de leeftijdsgroep van 21-30 jaar. Deze personen zullen dit niet-initieel onderwijs als een vorm van bijscholing volgen. Voor de gediplomeerden die zich in het eerste leeftijdscohort bevinden, zal de gevolgde nietinitiële opleiding daarentegen waarschijnlijk een beroepsopleiding zijn na de middelbare school ${ }^{15}$.

Tabel 4.7

Aantal gediplomeerden niet-initieel onderwijs naar beroepsgroep en leeftijdscohort, gemiddelde 1993-'95

Beroepsgroep

$\begin{array}{rrrr}\text { \# 20 } & \text { leeftijd } & & \\ \text { jaar } & 21-30 & 31-40 & 40 \\ & \text { jaar } & \text { jaar } & \text { jaar }\end{array}$

Pedagogische beroepen

$\begin{array}{rrrl}. & . & 4.200 & 3.700 \\ . & . & \cdot & \cdot \\ 3.100 & 16.700 & 8.800 & 3.600 \\ . & 2.600 & & \cdot \\ . & 5.800 & 5.300 & \cdot \\ 6.300 & 29.200 & 17.000 & 9.300 \\ . & . & 2.900 & \cdot \\ 5 . & . & 3.100 & . \\ 5.300 & 14.300 & 6.000 & 4.300\end{array}$

Culturele beroepen

Agrarische beroepen

Technische en industrieberoepen

Transportberoepen

Medische en paramedische beroepen

Economisch-administratieve beroepen

Informaticaberoepen

Sociaal-culturele beroepen

Verzorgende en dienstverlenende

beroepen

Openbare orde en veiligheids-

beroepen

Overig

. $\quad 2.800$

14.500

9.300

7.700

Totaal

25.100

96.100

61.800

35.600

. Er wordt niet voldaan aan de ondergrens van publicatie.

- Nihil.

Bron: ROA/CBS

Tabel 4.8

Aantal gediplomeerden niet-initieel voltijd/deeltijd/onbekend* onderwijs per beroepsgroep, gemiddelde 1994-'95

\begin{tabular}{lccc}
\hline Beroepsgroep & voltijd & deeltijd & onbekend \\
\hline Pedagogische beroepen & . & 4.600 & 4.600
\end{tabular}

15. Dit zal waarschijnlijk te maken hebben met de afbakening tussen regulier en niet-regulier onderwijs. 
Culturele beroepen

Agrarische beroepen

Technische en industrieberoepen

Transportberoepen

Medische en paramedische beroepen

11.900

16.100

Economisch-administratieve beroepen

Informaticaberoepen

4.900

7.200

$\begin{array}{lll}7.500 & 20.800 & 31.000\end{array}$

Sociaal-culturele beroepen

2.500

3.000

Verzorgende en dienstverlenende

2.600

3.600

4.900

10.300

15.800

beroepen

Openbare orde- en veiligheids-

beroepen

Overig

11.400

9.900

2.500

Totaal

32.600

74.100

16.800

107.200

\footnotetext{
* Van het jaar '93 uit de OR '95/'96 is niets bekend betreffende de vraag of de gediplomeerden die een niet-initiële opleiding volgen dit in voltijd dan wel deeltijd doen.

. Er wordt niet voldaan aan de ondergrens van publicatie.
}

Bron: ROA/CBS

Tabel 4.8 laat hetzelfde beeld zien als tabel 4.4: het meeste niet-initieel onderwijs wordt in deeltijd gevolgd. Alleen in de sector Overig wordt het meeste niet-initiële onderwijs in voltijd gevolgd.

Tabel 4.9 geeft een overzicht van het gevolgde niet-initieel onderwijs naar opleidingsniveau per bedrijfssector. Maar liefst $28 \%$ van de gediplomeerden in het niet-initieel onderwijs is werkzaam in de sector Landbouw en visserij en in de sector Kwartaire diensten. De participatiegraad in het niet-initieel onderwijs per bedrijfssector schommelt tussen $0,3 \%$ van de werkenden in de bedrijfssector Energie en 11\% voor de sector Landbouw en visserij. Hierbij wordt het meeste niet-initieel onderwijs op MBO-niveau gevolgd. In het algemeen wordt in de meeste bedrijfssectoren het niet-initieel onderwijs in deeltijd gevolgd ${ }^{16}$. Uit deze tabel blijkt ook dat in de verschillende bedrijfssectoren nauwelijks niet-initieel onderwijs op WO niveau wordt gevolgd. Dit kan echter ook een vertekening zijn omdat het aantal opleidingen op WO niveau klein is.

16. De categorie onbekend wordt hier buiten beschouwing gelaten. 
Tabel 4.9

Aantal gediplomeerden niet-initieel onderwijs naar opleidingsniveau per bedrijfssector, gemiddelde 1993-'95

\begin{tabular}{|c|c|c|c|c|c|}
\hline \multirow[t]{2}{*}{ Bedrijfssector } & \multicolumn{5}{|c|}{ niveau actuele opleiding } \\
\hline & VBO/MAVO & MBO & $\mathrm{HBO}$ & WO & totaal \\
\hline Landbouw en visserij & 4.400 & 18.900 & & . & 25.900 \\
\hline Voeding & & ter & & - & \\
\hline Chemie & - & . & & - & \\
\hline Metaal en elektrotechniek & . & . & & . & \\
\hline Overige industrie & . & . & & - & \\
\hline Energie & - & & - & - & \\
\hline Bouw en onroerend goed & . & 4.300 & . & . & 6.200 \\
\hline Handel & . & 15.000 & & . & 19.500 \\
\hline Transport en communicatie & & & & & 4.400 \\
\hline Bank en verzekeringswezen & & 5.000 & & . & 7.400 \\
\hline $\begin{array}{l}\text { Horeca, reparatie en zakelijke } \\
\text { dienstverlening }\end{array}$ & & $10 \mathrm{con}$ & & & \\
\hline $\begin{array}{l}\text { dienstverlening } \\
\text { Kwartaire diensten }\end{array}$ & $\begin{array}{l}2.500 \\
3.500\end{array}$ & 10.600 & 9700 & · & 16.400 \\
\hline Overheid en onderwijs & & 4.400 & 6.000 & & 12.900 \\
\hline Overig* & 13.700 & 53.300 & 13.700 & 3.700 & 84.400 \\
\hline Totaal & 32.100 & 138.200 & 38.700 & 9.400 & 218.500 \\
\hline
\end{tabular}

* In deze bedrijfssector zit ook de categorie onbekend.

. Er wordt niet voldaan aan de ondergrens van publicatie.

- Nihil.

Bron: ROA/CBS

Tabel 4.10 geeft een overzicht van het voltooide niet-initieel onderwijs per bedrijfssector, verbijzonderd naar leeftijdsgroep. In vrijwel alle sectoren bevinden de meeste gediplomeerden in het niet-initieel zich in de leeftijd van 21 tot 30 jaar. In de bedrijfssectoren Kwartaire diensten, Overheid en onderwijs en Overig wordt daarentegen relatief veel niet-initieel onderwijs op latere leeftijd gevolgd.

Uit tabel 4.11 blijkt dat - zoals verwacht mocht worden - in vrijwel alle bedrijfssectoren het grootste deel van het niet-initieel onderwijs in deeltijd wordt gevolgd. Met name in de sectoren Landbouw en visserij, Horeca, reparatie en zakelijke dienstverlening en de kwartaire diensten wordt echter nog een aanzienlijk aantal niet-initiële opleidingen in voltijd gevolgd. 
Tabel 4.10

Aantal gediplomeerden niet-initieel onderwijs naar bedrijfssector en leeftijdscohort, gemiddelde 1993-'95

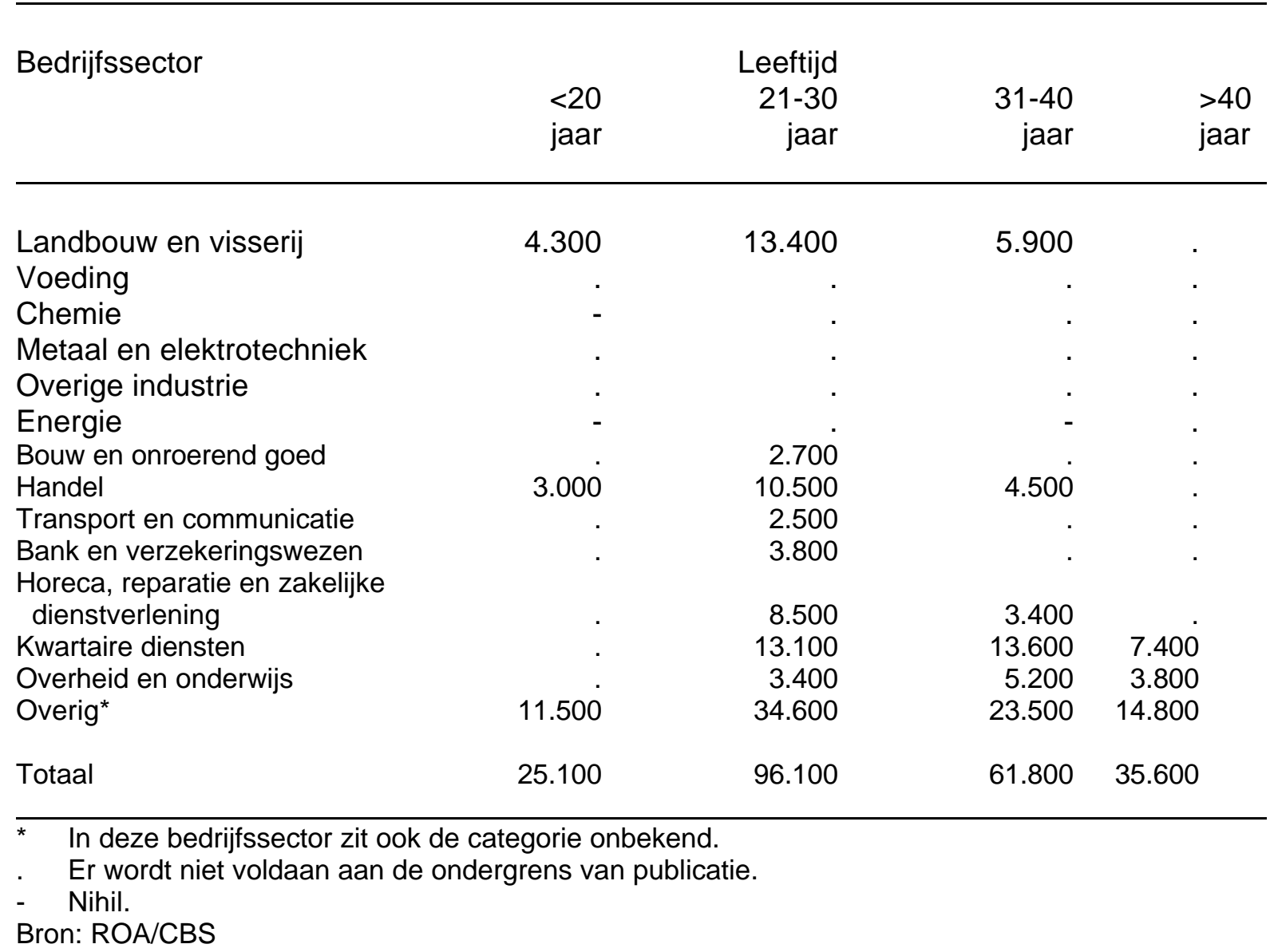

In het algemeen kan het volgende geconcludeerd worden:

1. Een relatief groot aantal werkenden heeft een niet-initiële opleiding gevolgd. Het risico dat dit gevolgen heeft voor de vervangingsvraag per opleidingstype indien iemands kwalificatieprofiel verandert, is hierdoor erg groot.

2. De scholingsparticipatie in het niet-initieel onderwijs betreft vooral niveau-verhogende opleidingen. Personen met een vooropleiding op MBO-niveau volgen zowel een niveau-verhogende als een richting-veranderende niet-initiële opleiding.

3. In een drietal beroepsgroepen wordt relatief veel niet-initieel onderwijs gevolgd, te weten: Technische en industrieberoepen, Economisch-administratieve beroepen en Verzorgende en dienstverlenende beroepen.

4. In een viertal bedrijfssectoren is de scholingsparticipatie in het niet-initieel onderwijs relatief groot, te weten: Landbouw en visserij, Handel, Kwartaire diensten en de sector Overig.

5. De leeftijd waarop wordt geparticipeerd in niveau-verhogend of opleidingsrichtingveranderend niet-initieel onderwijs is breed gespreid, al is er daarbij wel sprake van een concentratie in de leeftijdsgroepen van 21-30 jaar en 31-40 jaar.

Tabel 4.11 
Aantal gediplomeerden niet-initieel voltijd/deeltijd/onbekend ${ }^{*}$ onderwijs per bedrijfssector, gemiddelde 1994-'95

Bedrijfssector

voltijd

deeltijd

onbekend

Landbouw en visserij

3.800

8.900

12.300

Voeding

Chemie

Metaal en elektrotechniek

Overige industrie

Energie

Bouw en omroerend goed

Handel

Transport en communicatie

Bank- en verzekeringswezen

Horeca, reparatie en zakelijke dienstverlening

$(2.800$

Kwartaire diensten

Overheid en onderwijs

Overig

$\begin{array}{rrr}\cdot & \cdot & \cdot \\ \cdot & \cdot & \cdot \\ \cdot & \cdot & - \\ . & 6.500 & 3.000 \\ . & . & 9.400 \\ \cdot & . & 4.500 \\ . & 5.700 & 7.900 \\ 3.000 & 13.300 & 18.800 \\ 3.800 & 4.700 & 5.600 \\ 16.800 & 26.500 & 40.400 \\ 32.600 & 74.100 & 107.200\end{array}$

Totaal

32.600

74.100

* Van het jaar '93 uit de OR '95/'96 is niet bekend of de gediplomeerden die een niet-initiële opleiding volgen dit in voltijd dan wel deeltijd doen, dit jaar is hier dan ook buiten beschouwing gelaten.

. Er wordt niet voldaan aan de ondergrens van publicatie.

Bron: ROA/CBS

\section{Niet-initieel onderwijs en de vervangingsvraag per opleidingstype}

\subsection{Inleiding}

Indien een werkende na het verlaten van het initiële voltijd onderwijs een niveauverhogende of richting-veranderende niet-initiële opleiding voltooit, dan kan dit van invloed zijn op de prognose van de vervangingsvraag per opleidingstype. Bij de "vooropleiding" van degene die een dergelijke niet-initiële opleiding afsluit, wordt immers gemeten dat iemand met deze opleidingsachtergrond uitstroomt, terwijl bij het opleidingstype waartoe de nietinitiële opleiding wordt gerekend de netto-uitstroom in het desbetreffende leeftijdscohort afneemt. In dit hoofdstuk zal de relatie tussen de vervangingsvraag per opleidingstype en de scholingsparticipatie in het niet-initieel onderwijs worden geanalyseerd. 


\subsection{De vervangingsvraag ${ }^{17}$}

Voor het bepalen van de vervangingsvraag is een model ontwikkeld dat nauw aansluit bij de in demografische analyses vaker gebruikte cohort-componentenmethode. Deze methode maakt gebruik van standcijfers over de geslachts- en leeftijdsopbouw van de beroepsbeoefenaren over een aantal jaren ${ }^{18}$. Door van jaar op jaar een vergelijking te maken van de demografische opbouw in een bepaalde beroepsklasse of een bepaald opleidingstype, wordt een beeld gekregen van de (netto) in- of uitstroom voor het desbetreffende beroep of de desbetreffende opleiding. Op dit model zal hier kort worden ingegaan (zie voor een verdere toelichting Willems, 1999).

Kernpunt bij de methodiek voor de bepaling van de vervangingsvraag is de afleiding van de netto in- en uitstroomratio's. Deze ratio's weerspiegelen de relatieve toe- of afname van het aantal werkenden met een bepaalde opleidingsachtergrond ${ }^{19}$ van een bepaald geboortecohort gedurende een bepaalde periode. In symbolen kunnen de cohort-change-rates worden weergegeven als $^{20}$ :

$$
F_{b x}^{t-1}=\frac{W_{b x+1}^{t}-W_{b x}^{t-1}}{W_{b x}^{t-1}}
$$

\section{Waarbij:}

$\dot{F}_{b x}^{t-1}=$ netto in- of uitstroomratio van de werkenden met opleidingsrichting $b$ met leeftijd $x$ op tijdstip $t-1$, gedurende de periode $(t-1, t)$;

$W_{b x}^{t}=$ aantal werkenden met opleidingsrichting $b$ met leeftijd $x$ op tijdstip $t$.

Met behulp van de cohort-change-rate wordt de netto uitstroom, het saldo van uit- en instroom, in het verleden per opleidingsrichting bepaald, op basis van de beschikbare cijfers van de EBB. De vervangingsvraag die wordt opgevuld door (her-)intredende personen van hetzelfde leeftijdscohort (en geslacht) kan niet uit de beschikbare data worden afgeleid en wordt derhalve ook niet bij de bepaling van de vervangingsvraag meegenomen.

Vervolgens is een random-coëfficiënten-model geschat, waarbij de netto in- of uitstroom-

17. Deze paragraaf is gedeeltelijk gebaseerd op Borghans et al., 1997.

18. Zie voor de methodiek van de vervangingsvraagprognoses voor 1997-2002, Borghans et al. 1997.

19. De methodiek is hier uitgewerkt voor de vervangingsvraag per opleidingstype. De vervangingsvraag per beroepsklasse wordt op vrijwel analoge wijze bepaald.

20. Daarnaast zijn de ratio's verbijzonderd naar geslacht. Omwille van de overzichtelijkheid van de notatie is de geslachtsindex weggelaten. 
ratio's worden verklaard op basis van enerzijds de gemiddelde in- of uitstroom uit de totale werkzame bevolking en anderzijds beroepsspecifieke afwijkingen per geslacht en leeftijdscategorie. Een dergelijke aanpak garandeert dat de som van de netto stromen over de opleidingstypen overeenkomt met de totale in- of uitstroom.

Wanneer werkenden een niveau-verhogende dan wel richting-veranderende niet-initiële opleiding voltooien waardoor hun kwalificatieprofiel verandert, dan stromen zij uit bij het opleidingstype waartoe hun vooropleiding behoorde en stromen zij in bij het nieuwe opleidingstype. Echter, deze doorstroom wordt slechts bij de vervangingsvraag gemeten indien er bij het betreffende leeftijdscohort sprake is van een netto uitstroom. Wanneer er bij een bepaald leeftijdscohort sprake is van een netto instroom wordt de doorstroom naar een ander opleidingstype, vanwege het voltooien van een niet-initiële opleiding, niet meegenomen bij het bepalen van de vervangingsvraag. De vervangingsvraagprognoses dienen dan te worden opgehoogd met de doorstroom. In figuur 5.1 wordt dit schematisch weergegeven.

\section{Figuur 5.1}

Netto stromen van werkenden in een bepaald leeftijdscohort en hun implicaties voor de vervangingsvraagprognoses met de doorstroom naar een hoger of ouder opleidingstype

Vervangingsvraagprognoses

Netto instroom van werkenden Netto uitstroom van werkenden ophoging

geen ophoging

Vanzelfsprekend moet de doorstroom naar een ander opleidingstype niet alleen worden meegenomen bij de uitstroom bij het opleidingstype waartoe men daarvoor werd gerekend, maar ook bij de instroom van nieuwkomers van het opleidingstype waartoe de gevolgde niet-initiële opleiding wordt gerekend. Echter, ook hier geldt weer dat als er in het desbetreffende leeftijdscohort sprake is van een netto-uitstroom, er in feite reeds rekening is gehouden met de instroom van nieuwkomers. De weergegeven uitstroom heeft immers betrekking op de netto-uitstroom. Dit betekent dat de instroom van nieuwkomers van het opleidingstype, waartoe men behoort na het voltooien van de niet-initiële opleiding, alleen moet worden opgehoogd wanneer er reeds sprake is van een netto-instroom van de werkenden met deze opleidingsachtergrond in het desbetreffende leeftijdscohort. In figuur 5.2 wordt dit schematisch weergegeven.

Dit alles betekent dat zowel bij de vooropleiding als bij de nieuwe opleidingsachtergrond afzonderlijk moet worden bekeken of de vervangingsvraagprognoses (bij de vooropleiding) of de arbeidsmarktinstroom (bij de nieuwe opleidingsachtergrond) moet worden opgehoogd. Stel dat bijvoorbeeld een VBO'er in de leeftijdsgroep van 20-24 jaar een nietinitiële opleiding op MBO niveau voltooit. Indien er zowel bij de VBO als MBO opleiding in deze leeftijdsgroep een netto instroom wordt geconstateerd dan dienen zowel de arbeids- 
marktinstroomprognoses bij de MBO opleiding als de vervangingsvraagprognoses bij de VBO opleiding opgehoogd te worden. Wordt echter op MBO niveau in deze leeftijdsgroep een netto uitstroom geconstateerd dan dienen alleen de vervangingsvraag- prognoses bij de VBO opleiding opgehoogd te worden.

\section{Figuur 5.2}

Netto stromen en hun implicaties voor het ophogen van de arbeidsmarktinstroomprognoses met de doorstroom vanuit een lager of ander opleidingstype

Arbeidsmarktinstroomprognoses

Netto instroom van werkenden Netto uitstroom van werkenden ophoging

geen ophoging

Om de totale vervangingsvraag voor een bepaald opleidingstype te bepalen, is er bij de vervangingsvraagprognoses voor 1997-2002 ad hoc gecorrigeerd voor de uitstroom uit het niet-initieel onderwijs. Daarbij is voor iedereen die een niet-initiële opleiding voltooit en jonger is dan 40 jaar, de initiële vooropleiding bepaald. Deze participant stroomt uit bij deze initiële vooropleiding. Deze uitstroom is vervolgens opgeteld bij de vervangingsvraagprognose voor het desbetreffende opleidingstype op basis van de cohort-change-rate methodiek. De gehanteerde leeftijdsgrens van 40 jaar is echter arbitrair. Bovendien mag worden aangenomen dat de leeftijdsgrens waarbij de doorstroom naar een hoger opleidingstype al is ingecalculeerd bij de vervangingsvraagprognose per opleidingsniveau of -richting zal verschillen.

\subsection{Stroompatronen bij de vervangingsvraag}

Om de invloed van niet-initieel onderwijs op de vervangingsvraag te bestuderen per opleidingsniveau en -type, is een tweetal analyses uitgevoerd. Hierbij gaat het om de volgende vragen:

1. Bij welk leeftijdscohort voor de verschillende opleidingsniveaus ligt het omslagpunt waarbij de uitstroomcijfers van negatief naar positief omslaan?

2. Welke opleidingstypen vormen een uitzondering op het patroon dat bij punt 1. per opleidingsniveau wordt vastgesteld?

Deze twee analyses zijn afzonderlijk voor de mannen en vrouwen uitgevoerd vanwege de grote verschillen in het uitstroompatroon van beide geslachten. Bij de analyses zijn de leeftijden telkens gesplitst in leeftijdscohorten van vijf jaren. 
Tabel 5.1

Omslagpunt netto-stromen* naar opleidingsniveau, leeftijd en geslacht, gemiddelde 1993-'95

\begin{tabular}{|c|c|c|}
\hline Opleidingsniveau & leeftijd in jaren & netto-stromen \\
\hline \multicolumn{3}{|l|}{ Man } \\
\hline VBO & $15-19$ & netto-instroom \\
\hline VBO & $20-29$ & netto-uitstroom \\
\hline VBO & $30-34$ & netto-instroom \\
\hline VBO & $35-39$ & netto-uitstroom \\
\hline MBO & $15-39$ & netto-instroom \\
\hline $\mathrm{HBO}$ & $15-39$ & netto-instroom \\
\hline WO & $15-34$ & netto-instroom \\
\hline WO & $35-39$ & netto-uitstroom \\
\hline \multicolumn{3}{|l|}{ Vrouw } \\
\hline VBO & $15-19$ & netto-instroom \\
\hline VBO & $20-34$ & netto-uitstroom \\
\hline VBO & $35-39$ & netto-instroom \\
\hline MBO & $15-24$ & netto-instroom \\
\hline MBO & $25-29$ & netto-uitstroom \\
\hline MBO & $30-39$ & netto-instroom \\
\hline $\mathrm{HBO}$ & $15-24$ & netto-instroom \\
\hline $\mathrm{HBO}$ & $25-34$ & netto-uitstroom \\
\hline $\mathrm{HBO}$ & $35-39$ & netto-instroom \\
\hline Wo & $20-34$ & netto-instroom \\
\hline WO & $35-39$ & netto-uitstroom \\
\hline
\end{tabular}

* Alleen stroomcijfers die betrekking hebben op meer dan 100 mensen, zijn in deze tabel meegenomen.

Bron: ROA

Tabel 5.1 geeft een overzicht van de leeftijdsgroepen, waarbij voor een bepaald opleidingsniveau een netto-instroom van werkenden omslaat in een netto-uitstroom. Bij de mannen met een opleiding op VBO niveau zien we in de jongste leeftijdsgroep een netto-instroom als gevolg van de arbeidsmarktinstroom uit het initieel onderwijs. Opmerkelijk genoeg is er tussen de 20 en 29 jaar echter reeds sprake van een netto-uitstroom van werkenden met deze opleidingsachtergrond. De netto-uitstroom in deze leeftijdsgroep is waarschijnlijk een gevolg van het voltooien van een niet-initiële niveau-verhogende opleiding. In de leeftijdsgroep van 30-34 jaar kan weer een netto-instroom worden geconstateerd, mogelijk het gevolg van het voltooien van een niveau verhogende niet-initiële opleiding waarbij de vooropleiding op basisschool niveau lag (ongeschoold). Bij de mannelijke werkzame beroepsbevolking kan in de leeftijd tussen 35 en 39 een netto-uitstroom worden geconstateerd. Deels zou dit mogelijk het gevolg kunnen zijn van "niveau-verhogend doorleren" maar wellicht is het een gevolg van fysiek zware arbeid, of een uitstroom uit de 
werkgelegenheid vanwege reorganisaties, of dat men te duur wordt in vergelijking met jongere arbeidskrachten.

Bij de mannelijke werkzame beroepsbevolking op $\mathrm{MBO}$ en $\mathrm{HBO}$ niveau zien we een systematisch patroon bij alle leeftijdsgroepen tussen 15 en 39 jaar, er is sprake van een netto-instroom. De netto-instroom op latere leeftijd, vanaf 30 tot 39 jaar, is waarschijnlijk voor een belangrijk deel een gevolg van niveau-verhogend niet-initieel onderwijs. Wordt op WO niveau gekeken dan zien we reeds een netto-uitstroom in de leeftijd tussen 35 en 39 jaar.

Bij vrouwen wordt eveneens een redelijk normaal patroon bij de netto in- en uitstroom geconstateerd. Hier is het zogenoemde "kinderdal" waarneembaar. Dit wil zeggen dat vrouwen op een bepaalde leeftijd uitstromen om de zorg voor de eigen kinderen en daarna weer instromen als deze kinderen weer wat ouder zijn. In het algemeen kan gezegd worden dat hoe hoger het opleidingsniveau is, hoe hoger de leeftijd is waarop een nettouitstroom wordt waargenomen. Door dit kinderdal is het moeilijk om enige conclusies omtrent de netto in- en uitstroom patronen als gevolg van het voltooien van niet-initieel onderwijs te trekken.

Aan de hand van de stroomcijfers uit de bovenstaande tabel kunnen de volgende conclusies worden getrokken:

1. Bij de opleidingen op VBO niveau in de leeftijdsgroep van 15 tot 19 jaar moeten de instroom- en vervangingsvraagprognoses worden opgehoogd met het aantal mensen dat een niet-initiële opleiding op dit niveau voltooit. Daarbij moet de vervangingsvraagprognose opgehoogd worden met de niveau-verhogende of richting-veranderende doorstroom vanwege het voltooien van een niet-initiële opleiding.

2. Voor de 20 tot 30 jarigen die een VBO opleiding voltooien dient de vervangingsvraag niet te worden opgehoogd, omdat bij dit leeftijdscohort de vervangingsvraagprognose een netto-uitstroom vaststelt. Dit betekent dat de in- en uitstroom op dit opleidingsniveau als gevolg van het voltooien van een niveau-verhogende niet-initiële opleiding reeds wordt meegenomen bij deze leeftijdsgroep. Bij de arbeidsmarktinstroomprognoses dient deze ophoging wel plaats te vinden.

3. Bij de leeftijdsgroep van 30 tot 35 jaar zullen de instroom- en vervangingsvraagprognoses weer moeten worden opgehoogd omdat bij deze leeftijdsgroep een netto-instroom kan worden vastgesteld.

4. Vanaf 35 jaar tot 40 jaar moeten de vervangingsvraagprognoses niet worden opgehoogd, omdat de doorstoom naar een hoger opleidingsniveau na het voltooien van een niet-initiële niveau-verhogende opleiding reeds is meegenomen bij de vervangingsvraagprognose. De arbeidsmarktinstroomprognoses dienen echter wel te worden opgehoogd.

5. Bij de mannelijke beroepsbevolking die werkzaam is op MBO-niveau moeten de arbeidsmarktinstroom- en de vervangingsvraagprognose tot aan de leeftijd van 40 jaar worden opgehoogd met de richting-veranderende en niveau-verhogende doorstroom vanwege 
het voltooien van een niet-initiële opleiding. Bij de vrouwelijke beroepsbevolking die werkzaam is op dit niveau moeten de vervangingsvraagprognoses vanaf 15 tot 24 jaar en vanaf 30 tot 39 worden opgehoogd. De arbeidsmarktinstroomprognoses vanaf 15 tot 24 jaar en vanaf 35 tot 39 jaar.

6. Bij de mannelijke beroepsbevolking die werkzaam is op HBO-niveau, geldt hetzelfde verhaal als bij de mannelijke beroepsbevolking die werkzaam is op MBO-niveau, tot 40 jaar dienen de prognoses van de vervangingsvraag en tot 35 jaar de arbeidsmarktinstroomprognoses te worden opgehoogd met de richting-veranderende en niveau-verhogende niet-initiële opleidingen. Bij de vrouwelijke beroepsbevolking werkzaam op dit niveau dienen de vervangingsvraagprognoses vanaf 15 tot 24 en vanaf 35-39 verhoogd te worden, echter de arbeidsmarktinstroomprognoses vanaf 35 tot 40 jaar.

7. Bij zowel de mannelijke als de vrouwelijk beroepsbevolking die werkzaam is op WO niveau dienen tot 35 jaar de vervangingsvraag- en de arbeidsmarktinstroomprognoses te worden opgehoogd. Vanaf 35 kan er een netto-uitstroom worden vastgesteld, dit betekent dat vanaf deze leeftijd de prognoses niet meer dienen te worden opgehoogd.

Zoals hierboven reeds is geconcludeerd is het voor de vrouwelijke werkzame beroepsbevolking moeilijk om iets te zeggen met betrekking tot het ophogen van de stroomcijfers indien er sprake is van een netto-instroom omdat bij deze groep sprake is van het zogenoemde kinderdal.

$\mathrm{Nu}$ voor ieder opleidingsniveau voor zowel de mannelijke werkzame beroepsbevolking als de vrouwelijke werkzame beroepsbevolking in het algemeen is vastgesteld bij welke leeftijd de tellingen zouden moeten worden opgehoogd, kan de vraag worden gesteld voor welke opleidingstypen een uitzondering op deze algemene regel per opleidingsniveau dient te worden gemaakt.

In bijlage 3 wordt een overzicht gegeven van de opleidingstypes waarvoor een uitzondering zou moeten worden gemaakt op het in tabel 5.1 geschetste algehele beeld per opleidingsniveau. Mede vanwege het soms geringe aantal waarnemingen in de verschillende leeftijdsgroepen per opleidingstype, kunnen het bij nieuwe prognoses echter andere opleidingstypen zijn die een afwijkend netto instroom- of netto uitstroompatroon hebben. Daarom is het van belang een directe relatie te leggen tussen het doorrekenen van de doorstroom naar een ander opleidingstype en de vervangingsvraagprognose. Ter vermijding van dubbeltellingen of het ontstaan van hiaten bij het doorrekenen van het effect van de doorstroom naar een ander opleidingstype vanwege het voltooien van een niet-initiële opleiding is het immers noodzakelijk dat de beslissing om de instroom en/of vervangingsvraagprognoses op te hogen direct wordt gerelateerd aan de leeftijdsgroepen waarvoor bij de vervangingsvraagprognoses voor een bepaald opleidingstype, geslacht en/of leeftijdsgroep een netto-instroom wordt geconstateerd.

\section{Samenvatting en conclusie}


In dit werkdocument is eerst onderzocht in hoeverre het gebruik van verschillende Onderwijsrekeningen en het gebruik van één of meerdere waarnemingsjaren de meting van het opleidingsniveau-verhogende of richting-veranderende effect van het niet-initieel onderwijs op de opleidingsachtergrond van het arbeidsaanbod beïnvloeden. Daarna is getracht een nader inzicht te verkrijgen in de aard van het gevolgde niet-initiële onderwijs en in het effect van het niet-initiële onderwijs op het niveau en de richting van de opleidingsachtergrond van nieuwkomers op de arbeidsmarkt.

Eerst is in hoofdstuk 2 de methodiek van de instroomprognoses kort besproken. Daarna is in hoofdstuk 3 ingegaan op de betrouwbaarheid van de cijfers van de Onderwijsrekeningen. Op basis van de analyses met betrekking tot het gebruik van de Onderwijsrekeningen kan het volgende geconcludeerd worden:

1. Bij de arbeidsmarktinstroomprognoses dient gebruik te worden gemaakt van de 9maanden bestanden, dat wil zeggen de jaarcijfers, daar deze een betrouwbaarder beeld geven van het aantal participanten in het niet-initiële onderwijs. De grotere actualiteit van de data uit het 7-maanden bestand weegt niet op tegen de betrouwbaarheid van het minder recente 9-maanden bestand.

2. In het algemeen geven de meerjaren cijfers meer betrouwbare informatie omtrent de scholingsparticipatie in het niet-initieel onderwijs dan de cijfers uit één waarnemingsjaar.

Vervolgens is in hoofdstuk 4 geanalyseerd op welke manier de samenstelling van het arbeidsaanbod wijzigt als gevolg van de uitstroom uit het niet-initieel onderwijs. Aan de hand van deze analyse kunnen de volgende conclusies worden getrokken:

3. Het aantal gediplomeerden in het niet-initiële onderwijs is in de jaren 1993-'95 afgenomen; het aantal gediplomeerden op WO vormt hier echter een uitzondering op.

4. In het algemeen ligt de gevolgde vooropleiding één niveau lager dan de actuele nietinitiële opleiding. Echter, het MBO is hier een uitzondering op. Op dit opleidingsniveau ligt de voltooide niet-initiële opleiding ook veel op hetzelfde niveau (richtingveranderend) als op het niveau van de vooropleiding.

5. De meeste gediplomeerden in het niet-initieel onderwijs hebben een opleiding voltooid op MBO niveau. Van hen bevindt zich het merendeel in de leeftijdsgroep van 21 tot 30 jaar. Het niet-initieel onderwijs wordt in het algemeen in deeltijd gevolgd.

6. In een drietal beroepsklassen wordt relatief veel niet-initieel onderwijs gevolgd, te weten: Technische en industrieberoepen, Economisch-administratieve beroepen en Verzorgende en dienstverlenende beroepen. Het niet-initieel onderwijs in deze beroepsgroepen wordt vooral op MBO-niveau gevolgd, de gediplomeerden bevinden zich voornamelijk in de leeftijdsgroep van 21 tot 30 jaar.

7. In een viertal bedrijfssectoren is de scholingsparticipatie in het niet-initieel onderwijs relatief groot, te weten: Landbouw en visserij, Handel, Kwartaire diensten en de sector Overig. Dit niet-initieel onderwijs wordt voornamelijk op MBO niveau gevolgd.

Ten slotte heeft in hoofdstuk 5 de relatie tussen de arbeidsmarktinstroomprognose en de vervangingsvraagprognose per opleidingstype centraal gestaan. Hierbij is per opleidingsniveau nagegaan tot op welke leeftijd de arbeidsmarktinstroom- en de vervangingsvraag- 
prognoses (netto-instroomcijfers) dienen te worden opgehoogd als gevolg van de doorstroom naar een hoger opleidingsniveau na het voltooien van een niet-initiële opleiding. Daarbij is opgevallen dat op VBO niveau reeds op jonge leeftijd een netto-uitstroom wordt gesignaleerd. Dit betekent dat er bij de vervangingsvraagprognose reeds rekening is gehouden met de doorstroom naar een hoger opleidingsniveau vanwege het voltooien van een niet-initiële opleiding. Bij het opstellen van prognoses is het noodzakelijk het al dan niet doorrekenen van de doorstroom naar een ander opleidingstype direct te relateren aan de onderliggende uitstroomcijfers van de vervangingsvraagprognose. Dit betekent dat de arbeidsmarktinstroom- en/of de vervangingsvraagprognose alleen worden opgehoogd wanneer er bij een bepaald opleidingstype in de desbetreffende leeftijdsgroep sprake is van een netto-instroom.

\section{Literatuur}

Borghans L., A. de Grip, J. Delmee, A. Matheeuwsen, W. Smits en J. van Loo (1997), Methodiek arbeidsmarktprognoses en -indicatoren 1997-2002, ROA-W-1997/6, Maastricht.

Centraal Bureau voor de Statistiek (1996), Onderwijsrekeningen 1995/1996, Voorburg/Heerlen.

Centraal Bureau voor de Statistiek (1997), Onderwijsrekeningen 1996/1997, Voorburg/Heerlen.

Matheeuwsen A. en A. de Grip (1997), De doorstroom van het initiële naar het niet-initiële onderwijs, ROA-W-1997/4, Maastricht.

Ministerie van Onderwijs, Cultuur en Wetenschappen (1997), Referentieraming 1997, Zoetermeer.

ROA (1996), Statische Bijlage De arbeidsmarkt naar opleiding en beroep tot 2000, Actualisering 1996, ROA-R-1996/8B, Maastricht.

ROA (1998), Statistische Bijlage De arbeidsmarkt naar opleiding en beroep tot 2002, Actualisering 1998, ROA-R-1998/9B, Maastricht.

Willems E. (1999), Modelling Replacement Demand: A Random Coefficient Approach, $\mathrm{R}$

Maastricht (verschijnt binnenkort). 


\section{Bijlage 1}

Opleidingstypen waarvan de 7-maanden cijfers een onderschatting laten zien ten opzichte van de 9-maanden cijfers (voor de verschillende opleidingsniveaus)

Opleidingsrichting

onbetrouwbaarheidsfactor

VBO vervoer

! 0,33

MBO landbouw en veeteelt

$! 0,26$

MBO milieu en groene ruimte

! 0,06

MBO bouw

! 0,41

MBO grafische techniek

! 0,29

MBO procestechniek

! 0,01

$\mathrm{MBO}$ vervoer

! 0,05

MBO dokters! , tandarts- en dierenartsassistent

! 0,14

$M B O$ verpleging

! 0,26

$\mathrm{MBO}$ horeca

! 0,02

MBO administratie

! 0,11

MBO handel

! 0,05

MBO secretariaat

! 0,34

HBO lerarenopleiding basisonderwijs

! 0,02

HBO elektrotechniek

! 0,36

HBO verpleegkunde

! 0,21

HBO (fysio)therapie

! 0,80

HBO accountancy en bedrijfseconomie

! 0,16

HBO secretariaat

! 0,15

HBO bedrijfskunde

! 0,10

HBO personeelswerk

! 0,13

WO landbouw en milieukunde

! 0,05

WO bedrijfskunde

! 0,24

Bron: ROA/CBS 


\section{Bijlage 2}

Tabellen 4.2, 4.3 en 4.4 met splitsing VBO en MAVO en HAVO/VWO en MBO

Toelichting Tabel 4.2

Aantal gediplomeerden niet-initieel onderwijs per opleidingsniveau naar vooropleiding, gemiddelde 1993-'95

Niveau actuele opleiding

Niveau vooropleiding

Basis-
onderwijs

\begin{tabular}{|c|c|c|c|c|c|c|c|}
\hline MAVO & & & & - & & & - \\
\hline $\begin{array}{l}\text { VBO } \\
\text { HAVO/VWO }\end{array}$ & 2.900 & $\begin{array}{l}3.100 \\
2600\end{array}$ & 6.300 & - & 13.400 & - & : \\
\hline $\mathrm{MBO}$ & 3.900 & 13.300 & 21.600 & 15.100 & 63.800 & 10.600 & \\
\hline $\mathrm{HBO}$ & . & & & 4.400 & 9.900 & 19.000 & 4.400 \\
\hline WO & - & - & - & . & . & 5.900 & . \\
\hline Totaal & 9.300 & 19.600 & 29.300 & 23.800 & 89.500 & 37.800 & 9.000 \\
\hline
\end{tabular}

. Er wordt niet voldaan aan de ondergrens van publicatie.

- Nihil.

Bron: ROA/CBS

Toelichting Tabel 4.3

Aantal gediplomeerden niet-initieel onderwijs per opleidingsniveau naar leeftijdscohort, gemiddelde 1993-'95

Opleidingsniveau

\begin{tabular}{llll} 
& \multicolumn{2}{c}{ Leeftijd } & \\
$\leq 20$ & $21-30$ & $31-40$ & $>40$ \\
jaar & jaar & jaar & jaar
\end{tabular}

MAVO
VBO
HAVO/VWO
MBO
HBO
WO

Totaal

$\begin{array}{rrrr}- & 14.300 & 8.600 & 6.600 \\ 2.600 & 4.100 & & . \\ 20.800 & 59.800 & 32.400 & 17.600 \\ . & 12.800 & 15.800 & 8.400 \\ - & 4.000 & 4.000 & .\end{array}$

$25.100 \quad 96.100 \quad 61.800 \quad 35.600$

. Er wordt niet voldaan aan de ondergrens van publicatie.

- Nihil.

Bron: ROA/CBS 
Toelichting Tabel 4.3

Aantal gediplomeerden niet-initieel voltijd/deeltijd/onbekend* onderwijs per opleidingsniveau, gemiddelde 1994-'95*

\begin{tabular}{lrrr}
\hline Opleidingsniveau & voltijd & deeltijd & onbekend \\
\hline MAVO & & & \\
VBO &. & 14.000 & 12.800 \\
HAVO & 3.600 & .500 \\
MBO & 20.000 & 43.000 & 63.100 \\
HBO & 4.400 & 15.100 & 18.800 \\
WO &. &. & 6.600 \\
Totaal & 32.600 & 74.100 & 107.200 \\
\hline
\end{tabular}

. Er wordt niet voldaan aan de ondergrens van publicatie.

- Nihil.

* Van het jaar 1993 uit de OR '95/'96 is niet bekend of de niet- initiële opleiding in voltijd of in deeltijd wordt gevolgd.

Bron: ROA/CBS 


\section{Bijlage 3}

Opleidingstypen die een uitzondering vormen op het systematische patroon in de stroomcijfers*, gemiddelde 1993-'95

Opleidingstype leeftijd in jaren

\begin{tabular}{|c|c|c|}
\hline \multicolumn{3}{|l|}{ Man } \\
\hline \multicolumn{3}{|l|}{ VBO Installatietechniek } \\
\hline VBO Bouwtechniek & $20-24$ & netto-instroom \\
\hline VBO Installatietechniek & $30-34$ & netto-uitstroom \\
\hline VBO Motorvoertuigentechniek & $35-39$ & netto-instroom \\
\hline VBO Elektrotechniek & $25-29$ & netto-instroom \\
\hline VBO Brood en banket & $20-24$ & netto-instroom \\
\hline \multirow[t]{2}{*}{ VBO Vervoer } & $20-30$ & netto-instroom \\
\hline & 35-39 & netto-instroom \\
\hline \multirow[t]{2}{*}{ VBO Administratie, handel en textiel } & $20-24$ & netto-instroom \\
\hline & $30-34$ & netto-uitstroom \\
\hline VBO Verzorging & $20-29$ & netto-instroom \\
\hline VBO Beveiliging & $20-24$ & netto-instroom \\
\hline MBO HAVO/ VWO & $20-29$ & netto-uitstroom \\
\hline MBO Landbouw en veeteelt & $30-34$ & netto-uitstroom \\
\hline MBO Milieu en groene ruimte & $30-34$ & netto-uitstroom \\
\hline MBO Laboratorium & $30-34$ & netto-uitstroom \\
\hline MBO Bouw & $25-34$ & netto-uitstroom \\
\hline \multirow[t]{2}{*}{ MBO Installatietechniek } & $25-29$ & netto-uitstroom \\
\hline & $35-39$ & netto-uitstroom \\
\hline MBO Werktuigbouw \& mechanische techniek & $25-39$ & netto-uitstroom \\
\hline MBO Fijnmechanische techniek & $20-29$ & netto-uitstroom \\
\hline MBO Motorvoertuigentechniek & $25-34$ & netto-uitstroom \\
\hline MBO Operationele techniek & $30-34$ & netto-uitstroom \\
\hline \multirow[t]{2}{*}{ MBO Elektrotechniek } & $25-29$ & netto-uitstroom \\
\hline & $35-39$ & netto-uitstroom \\
\hline MBO Grafische techniek & $35-39$ & netto-uitstroom \\
\hline MBO Brood en banket & $35-39$ & netto-uitstroom \\
\hline MBO Levensmiddelentechniek/vleesverwerking & $30-34$ & netto-uitstroom \\
\hline MBO Vervoer & $30-34$ & netto-uitstroom \\
\hline MBO Dokters-, tandarts- en dierenartsassistente & $30-34$ & netto-uitstroom \\
\hline MBO Verpleging & $20-24$ & netto-uitstroom \\
\hline MBO Sociaal-cultureel & $35-39$ & netto-uitstroom \\
\hline MBO Horeca & $30-39$ & netto-uitstroom \\
\hline MBO Administratie & $25-29$ & netto-uitstroom \\
\hline MBO Handel & 30-39 & netto-uitstroom \\
\hline \multirow[t]{2}{*}{ HBO Lerarenopleiding basisonderwijs } & $25-29$ & netto-uitstroom \\
\hline & $35-39$ & netto-uitstroom \\
\hline \multirow{2}{*}{$\begin{array}{l}\text { HBO Lerarenopleiding economie en maatschappij } \\
\text { HBO Lerarenopleiding medisch en verzorging }\end{array}$} & $35-39$ & netto-uitstroom \\
\hline & $30-34$ & netto-uitstroom \\
\hline \multirow{2}{*}{$\begin{array}{l}\text { HBO Lerarenopleiding expressie } \\
\text { HBO Tolk en vertaler }\end{array}$} & $25-29$ & netto-uitstroom \\
\hline & $35-39$ & netto-uitstroom \\
\hline HBO Landbouw en veeteelt & 30-34 & netto-uitstroom \\
\hline HBO Milieukunde en levensmiddelentechnologie & $30-30$ & netto-uitstroom \\
\hline
\end{tabular}

Opleidingstypen die een uitzondering vormen op het systematische patroon in de 


Opleidingstype leeftijd in jaren

$\begin{array}{lll}\text { HBO Laboratorium } & 20-24 & \text { netto-uitstroom } \\ \text { HBO Bouwkunde } & 30-34 & \text { netto-uitstroom } \\ \text { HBO Werktuigbouwkunde } & 30-34 & \text { netto-uitstroom } \\ \text { HBO Informatica } & 30-34 & \text { netto-uitstroom } \\ \text { HBO Chemische technologie } & 30-34 & \text { netto-uitstroom } \\ \text { HBO Vervoer en logistiek } & 35-39 & \text { netto-uitstroom } \\ \text { HBO Verpleegkunde } & 30-39 & \text { netto-uitstroom } \\ \text { HBO (Fysio)therapie } & 30-34 & \text { netto-uitstroom } \\ \text { HBO Commerciële economie } & 30-39 & \text { netto-uitstroom } \\ \text { HBO Toerisme en recreatie } & 35-39 & \text { netto-uitstroom } \\ \text { HBO Recht en bestuur } & 25-39 & \text { netto-uitstroom } \\ \text { HBO Bedrijfskunde } & 35-39 & \text { netto-uitstroom } \\ \text { HBO Communicatie en journalistiek } & 35-39 & \text { netto-uitstroom } \\ \text { HBO Bibliotheek en documentatie } & 25-29 & \text { netto-uitstroom } \\ \text { HBO Uitvoerende en beeldende } & 35-39 & \text { netto-uitstroom } \\ \text { HBO Openbare orde en veiligheid } & 25-29 & \text { netto-uitstroom } \\ & 35-39 & \text { netto-uitstroom } \\ \text { WO Landbouw en milieukunde } & & \\ \text { WO Elektrotechniek } & 30-34 & \text { netto-uitstroom } \\ \text { WO Informatica en bestuurlijke informatiekunde } & \text { netto-uitstroom } \\ \text { WO (Dier)geneeskunde } & 35-34 & \text { netto-instroom } \\ \text { WO Farmacie } & 30-34 & \text { netto-uitstroom } \\ & 20-24 & \text { netto-uitstroom } \\ \text { WO Bedrijfskunde } & 35-39 & \text { netto-instroom } \\ \text { WO Kunstwetenschappen } & 30-34 & \text { netto-uitstroom } \\ & 35-39 & \text { netto-instroom } \\ \text { Vrouw } & 35-39 & \text { netto-instroom } \\ \text { VBO Horeca en levensmiddelentechniek } & 35-39 & \text { netto-instroom } \\ \text { VBO Verzorging } & & \\ \text { VBO Beveiliging } & 30-34 & \text { netto-instroom } \\ \text { MBO HAvO/VwO } & 35-39 & \text { netto-uitstroom } \\ \text { MBO Landbouw en veeteelt } & 30-34 & \text { netto-instroom } \\ \text { MBO Milieu en groene ruimte } & 20-29 & \text { netto-instroom } \\ \text { MBO Laboratorium } & & \\ \text { MBO Grond-, weg en waterbouw } & 20-24 & \text { netto-uitstroom } \\ \text { MBO Levensmiddelentechniek/vleesverwerking } & \text { netto-instroom } \\ \text { MBO Apothekers assistent } & 25-29 & \text { netto-uitstroom } \\ \text { MBO Verpleging } & 30-34 & \text { netto-uitstroom } \\ \text { MBO Verzorging } & 30-34 & \text { netto-uitstroom } \\ \text { HBito-uitstroom }\end{array}$

Opleidingstypen die een uitzondering vormen op het systematische patroon in de stroomcijfers*, gemiddelde 1993-’95 (vervolg) 


$\begin{array}{lll}\text { MBO Horeca } & 25-29 & \text { netto-instroom } \\ \text { MBO Beweging en therapie } & 25-29 & \text { netto-instroom } \\ & 35-39 & \text { netto-uitstroom } \\ \text { MBO Administratie } & 25-29 & \text { netto-instroom } \\ \text { MBO Handel } & 30-39 & \text { netto-uitstroom } \\ \text { MBO Openbare orde en veiligheid } & 25-29 & \text { netto-instroom } \\ & & \\ \text { HBO Lerarenopleiding talen } & 30-34 & \text { netto-instroom } \\ \text { HBO Lerarenopleiding natuur en techniek } & 35-39 & \text { netto-uitstroom } \\ \text { HBO Lerarenopleiding economie en maatschappij } & 25-29 & \text { netto-instroom } \\ \text { HBO Lichamelijke opvoeding } & 25-34 & \text { netto-instroom } \\ \text { HBO Lerarenopleiding medische en verzorging } & 25-29 & \text { netto-instroom } \\ \text { HBO Lerarenopleiding expressie } & 30-34 & \text { netto-instroom } \\ \text { HBO Landbouw en veeteelt } & 35-39 & \text { netto-instroom } \\ \text { HBO Laboratorium } & 30-34 & \text { netto-uitstroom } \\ \text { HBO Civiele techniek } & 30-34 & \text { netto-instroom } \\ \text { HBO Informatica } & 25-29 & \text { netto-instroom } \\ \text { HBO Vervoer en logistiek } & 35-39 & \text { netto-instroom } \\ \text { HBO Verpleegkunde } & 25-34 & \text { netto-uitstroom } \\ \text { HBO (Fysio)therapie } & 25-34 & \text { netto-instroom } \\ \text { HBO Voeding } & 35-39 & \text { netto-instroom } \\ \text { HBO Accountancy en bedrijfseconomie } & 25-29 & \text { netto-uitstroom } \\ \text { HBO Commerciële economie } & 25-34 & \text { netto-instroom } \\ \text { HBO Recht en bestuur } & 25-29 & \text { netto-instroom } \\ \text { HBO Secretariaat } & 30-34 & \text { netto-instroom } \\ \text { HBO Bedrijfskunde } & 35-39 & \text { netto-instroom } \\ \text { HBO Communicatie en journalistiek } & 35-39 & \text { netto-uitstroom } \\ \text { HBO Maatschappelijk werk en hulpverlening } & 35-39 & \text { netto-uitstroom } \\ \text { HBO Personeelswerk } & 25-29 & \text { netto-uitstroom } \\ \text { WO Letteren } & 30-34 & \text { netto-instroom } \\ \text { WO Theologie } & 30-34 & \text { netto-instroom } \\ \text { WO Bedrijfskunde } & & \text { netto-instroom } \\ \text { WO Rechten en bestuurskunde } & 25-29 & \text { netto-uitstroom } \\ & 35-39 & \text { netto-instroom } \\ \text { netto-uitstroom } \\ \text { HBito } & 30-34 & \text { netto-instroom } \\ \text { netto-uitstroom }\end{array}$

* Alleen stroomcijfers met een absolute waarde > 100, zijn in deze tabel meegenomen. Bron: ROA 